\title{
LA FIGURA DE LAS LARGAS CEJAS DE LA ICONOGRAFÍA SANTAMARIANA. CHAMANISMO, SACRIFICIO Y COSMOVISIÓN CALCHAQUÍ
}

\section{THE FIGURE WITH LONG EYEBROWS IN SANTAMARIANA ICONOGRAPHY. SHAMANISM, SACRIFICE AND THE CALCHAQUÍ COSMOVISION}

\section{JAVIER NASTRI *}

El género discursivo de las urnas funerarias santamarianas,
producido en el marco de la sociedad calchaquí, estuvo en
vigencia entre los siglos xi y xvi a lo largo de una extendida
sección de la Subárea Valliserrana del actual Noroeste Argentino.
Su aspecto temático principal está dado por una figura central
denominada "de las largas cejas". El presente texto analiza las
características que asume la representación de esta figura en
una amplia muestra constituida por piezas enteras de museos.
Se propone que elementos tales como arreglos cefálicos,
cabezas trofeo y otros referentes significativos del simbolismo
calchaquí, constituyen indicadores de una cosmovisión de tipo
chamánica y sacrificial.

Palabras clave: urnas funerarias, sacrificio, chamanismo, iconografía, simbolismo, cosmovisión

The Santamariana discursive genre funerary urns produced by the Calchaqui society were used from the $11^{\text {th }}$ to $17^{\text {th }}$ century in a vast part of present-day Northwest Argentina's Valliserrana subarea. The genre's main subject is a central figure referred to as "of long eyebrows". The present text analyzes the characteristics of this representation in a broad sample of complete museum artifacts. It is proposed that cephalic adornments, trophy heads and other key referents in Calchaqui symbolism stand as indicators of the importance of ideas and concepts belonging to a sacrificial-type cosmovision.

Key words: funerary urns, sacrifice, shamanism, iconography, symbolism, cosmovision
Las diferentes definiciones de "estilo" se relacionan, por lo general, con la descripción de conjuntos de rasgos con ciertas características, que permiten asociar entre sí objetos culturales diversos; ya sea que compartan o no el mismo medio, lenguaje o género (Steimberg 1993: 59). Se trata entonces de una propiedad relacional de buena parte de los eventos comprendidos en una época o período (Hodder 1990: 45). En la práctica arqueológica los estilos son considerados representaciones visuales propias de un tiempo y lugar específicos, y, al menos, transmiten información acerca de la identidad de la sociedad que las produjo (Rice 1987: 244).

Las urnas santamarianas constituyen el género privilegiado para la expresión del estilo santamariano y, en tal sentido, permiten su inmediata identificación. De hecho, ha sido el primer estilo definido en la arqueología argentina (Lafone Quevedo 1892). Y más allá de los aspectos morfológicos y técnicos de la cerámica, la representación de una figura central a la cual, a falta de un nombre mejor, denominaré de las largas cejas, constituye otro elemento básico que permite la asignación de un vasto conjunto de piezas a un mismo grupo. En el presente artículo abordaré el tema de la forma de representación de la mencionada figura a partir del análisis de una muestra de 756 piezas enteras conservadas en diferentes museos de Argentina, Europa y Estados Unidos. ${ }^{1}$ Me centraré en aquellas variantes de representación del rostro y del

\footnotetext{
* Javier Nastri, COnicet - Museo Etnográfico J. B. Ambrosetti, Universidad de Buenos Aires, Moreno 350, Buenos Aires (1091), Argentina, email: jnastri@daad-alumni.de
} 
cuerpo más relevantes para discutir la pertinencia de asociar la imaginería calchaquí a concepciones de carácter chamánico y sacrificial. Buscaré mostrar que este aspecto resulta de gran importancia para la comprensión de los cambios históricos principales experimentados por los antiguos calchaquíes; belicoso pueblo que vivió en un amplio sector de los valles y quebradas del actual Noroeste Argentino, entre los siglos XI y XVII de la Era (Tarragó 2000; Nastri 2003; Greco 2005).

\section{COSMOLOGÍAS}

En su ya clásica obra sobre los sistemas totémicos de clasificación, Lévi-Strauss (1964: 326) destacó que éstos se basaban en la metáfora (una homología entre la serie de las especies naturales y la de los grupos sociales) y los contrapuso con la lógica del sacrificio, a la que asoció con el desarrollo de relaciones metonímicas entre significantes: las especies naturales forman aquí un continuum que media, a través de sucesivas identificaciones, entre la humanidad y la divinidad. En tiempos recientes, varios autores destacaron la necesidad de que el sacrificio contara con un tratamiento similar al que tuvo el totemismo, proponiendo que la más adecuada noción para contrastar con este último sería la de animismo (Descola 1992; Viveiros de Castro 2005: 341). Esta cosmología, o modo de identificación, apela a categorías sociales para significar relaciones entre especies diferentes, atendiendo a la idea de que todas las especies que pueblan el cosmos poseen conciencia e intencionalidad (Descola 2006). Dentro de esta manera de pensar, la humanidad es sólo uno de los puntos de vista disponibles para ser adoptados por un individuo, más allá de su naturaleza biológica. En el contexto de esta noción perspectivista, resulta entonces central la función del chamán, definido a partir de la capacidad que poseen algunos humanos para atravesar las barreras corporales a fin de adoptar las perspectivas de las subjetividades no humanas (Viveiros de Castro 2005: 342-343). El chamanismo difiere del sacerdocio en el hecho de que los chamanes producen la conexión con otras subjetividades a través de su propio cuerpo. Otras cualidades de la ideología chamánica clásica son: 1) la naturaleza estratificada del cosmos; 2) la creencia en un tiempo mítico, cuando era posible moverse entre los distintos mundos; 3) la reproducción del cosmos estratificado al interior de cada individuo; 4) el chamán como "dueño" de los animales y como medio de contacto con el mundo sobrenatural; 5) un rol importante de los animales en el vuelo chamánico, y 6) un carácter fálico y agresivo (Reichel-Dolmatoff 1988; Price 2001).
Hugh-Jones (1996: 37) distinguió dos tipos de chamanismo: el "horizontal" y el "vertical". Chamanes horizontales son aquellos típicamente guiados por la inspiración y que muestran grandes dosis de carisma a través de sus acciones, a la vez que, con frecuencia, su conducta es moralmente ambigua y agresiva. Este tipo de chamán se encuentra principalmente en sociedades de un tipo más igualitario y belicoso. Por el contrario, la figura del chamán vertical es más próxima a la de un sacerdote y corresponde a sociedades más jerárquicas y pacíficas (Hugh-Jones 1996). Más aún, para Viveiros de Castro (2005: 346) el sacerdocio es el producto de la transformación de la función chamánica, una vez que valores tales como ancestralidad (continuidad entre gente muerta y viva) y jerarquía (discontinuidad entre gente viva) han emergido en una sociedad. En contraste, el régimen cosmológico del chamanismo horizontal establece que la distancia entre los vivos y los muertos es mayor que aquella existente entre los muertos y los animales.

En una obra reciente, Descola (2006) ha propuesto un esquema de cuatro ontologías de la praxis, para organizar el conjunto de nociones desarrolladas en los últimos años en referencia al tema. Al totemismo y el animismo, Descola agrega el naturalismo, propio de la sociedad moderna, y el analogismo, una cosmología extendida durante siglos en buena parte del globo. Combina en su esquema las nociones de fisicalidad e interioridad con las de continuidad y discontinuidad (fig. 1). De esta manera, a la inversa del animismo, el naturalismo de la sociedad moderna asume la continuidad de las fisicalidades (todas las especies del reino animal) y la discontinuidad de las interioridades (sólo el hombre posee conciencia). En el analogismo, por último, como reverso del totemismo, en lugar de usarse la metáfora para el establecimiento de diferencias sobre un universo percibido como continuo, se apela a dicho dispositivo retórico para la superación de una verdadera proliferación de entidades discontinuas y singulares, tanto en el plano de las fisicalidades como de las interioridades.

Las sociedades no se limitan a la asimilación de una única cosmología, sino que por lo general articulan varias, siendo una la predominante (Descola 2006: 148). Ésta, por su parte, constituye también una forma de concebir al colectivo y al sujeto social, lo que trae consigo una problemática intelectual particular a resolver por medio de la praxis (Pazos 2006: 188). El arte vinculado a la práctica funeraria proporciona un rico corpus de expresión de valores culturales que permite explorar la cuestión de la presencia de significados vinculados a algunas de las cosmologías mencionadas. 


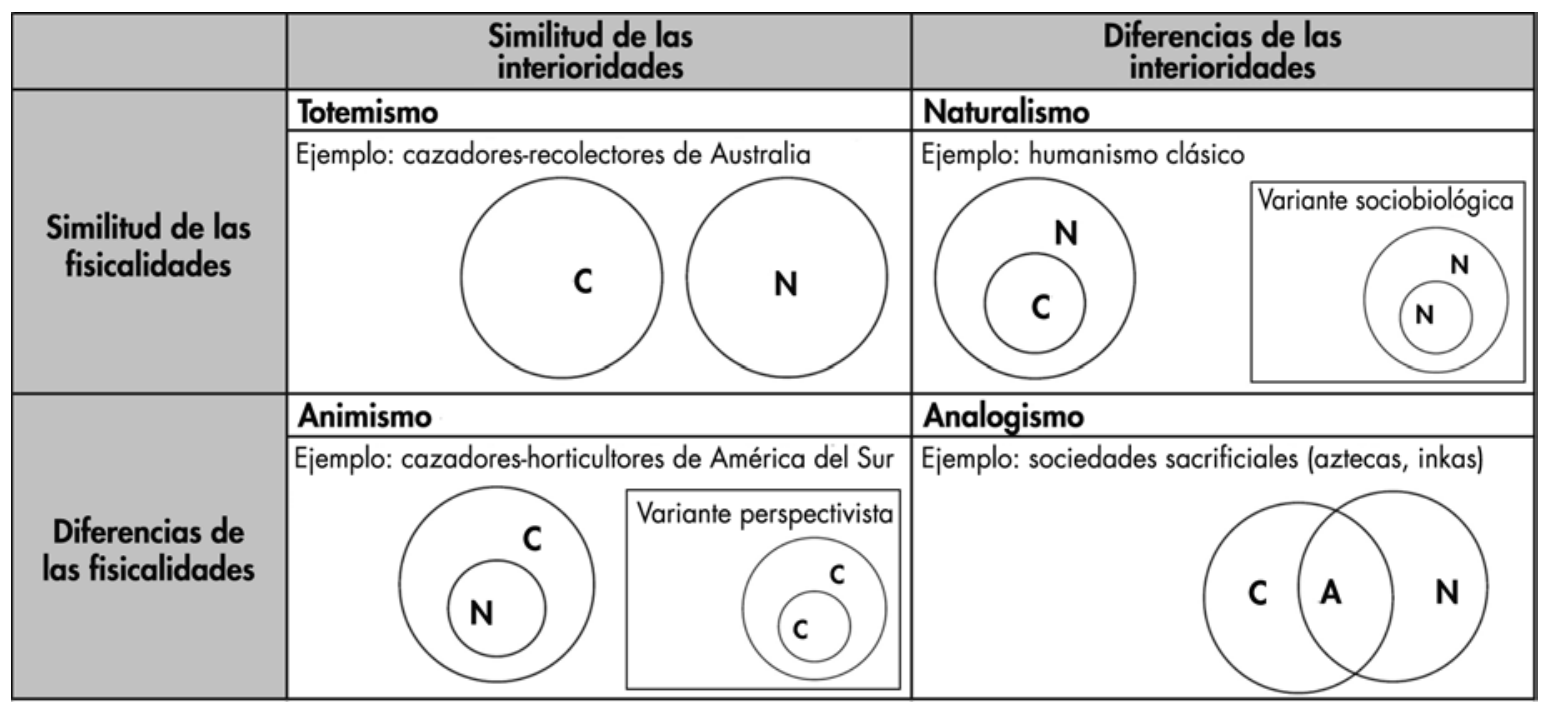

Figura 1. Tipología de ontologías de la praxis de Descola (2006), modificado de Callens (2006) y Mendes do Santos (2002) Figure 1. Typology of Descola's praxis ontologies (2006), modified from Callens (2006) and Mendes do Santos (2002).

\section{EL ARTE SANTAMARIANO}

Las piezas más características del estilo cerámico santamariano son las urnas y los pucos. Luego cabe considerar ollas, miniaturas de urnas y de pucos, figurillas modeladas y grandes urnas de tipo aribaloide. En lo que respecta a la pasta, los distintos tipos tienen en común la presencia de mica y de tiesto molido, como antiplástico. La compactación es variable, correspondiendo las mejores pastas a la variedad tricolor (Piñeiro 1996; Palamarczuk 2008). A excepción de algunas figurillas que sólo presentan baño en la superficie, todos los tipos presentan decoración pintada; mayoritariamente en colores negro y rojo sobre fondo blanco (variedad tricolor), negro sobre blanco (variedad bicolor) y, en mucha menor frecuencia, negro sobre rojo (Marchegiani et al. 2007).

Fragmentos de estas piezas cerámicas decoradas abundan en la superficie de los yacimientos que contienen restos de las poblaciones locales de los últimos tres períodos de la etapa agroalfarera de la región (Tardío, Imperial e Hispano-Indígena), desarrollados aproximadamente entre los años 1000 y $1670 \mathrm{DC}^{2}{ }^{2} \mathrm{La}$ proporción en que se manifiesta el tipo santamariano en los conjuntos cerámicos de los sitios del valle de Santa María o Yocavil, en las actuales provincias argentinas de Catamarca, Tucumán y Salta (fig. 2), es igual o mayor a la de la cerámica no decorada (Palamarczuk 2008). Los ejemplares de piezas completas que se encuentran en numerosos museos del mundo corresponden a hallazgos realizados en contextos funerarios. En dichos contextos las grandes urnas contienen, por lo general, esqueletos de individuos neonatos y aparecen tapadas por pucos colocados boca abajo. En ocasiones, el lugar de los pucos es ocupado por lajas planas. Las urnas pueden llenar el espacio de una cámara cilíndrica estrecha, o bien aparecer contiguas a otras con idéntico contenido en cámaras más amplias, junto a individuos fuera de urnas y acompañados de otros objetos. Miniaturas, ollas y pucos corresponden por lo general a este último grupo, pudiendo haber contenido, los últimos, líquidos y alimentos destinados al consumo del difunto.

Las urnas son vasijas alargadas, de entre 50 y 60 $\mathrm{cm}$ de alto por $35 \mathrm{~cm}$ de ancho aproximadamente, que pueden dividirse en tres partes: un cuello cilíndrico, por lo general evertido, un cuerpo ovoide y una base cónica constituida por un puco (fig. 3). Las asas, casi siempre acintadas, se ubican en los laterales del cuerpo, donde se disponen franjas negras que se ensanchan en la mitad de la pieza o en la base. En algunos casos puede haber otro par de apéndices, modelados en los laterales del cuello (asas trenzadas, moños) o en la parte superior del cuerpo (cabezas humanas). Las caras frontales de la pieza están reservadas para la decoración pintada (en ocasiones combinada con aplicaciones modeladas) de un personaje antropomorfo caracterizado por presentar largas cejas. El rostro de dicho personaje se dispone sobre el cuello de la pieza, en cuyas mejillas hay decoraciones geométricas o figurativas, probablemente representando decoración facial. ${ }^{3}$ En los casos en que se apela al uso del pastillaje (agregado de porciones de pasta modelada sobre la superficie de la vasija), éste se limita a la figuración de cejas, ojos y, con menor frecuencia, nariz. Sólo en algunas variantes propias de la zona de Pampa Grande o Santa Bárbara (véase fig. 2) 


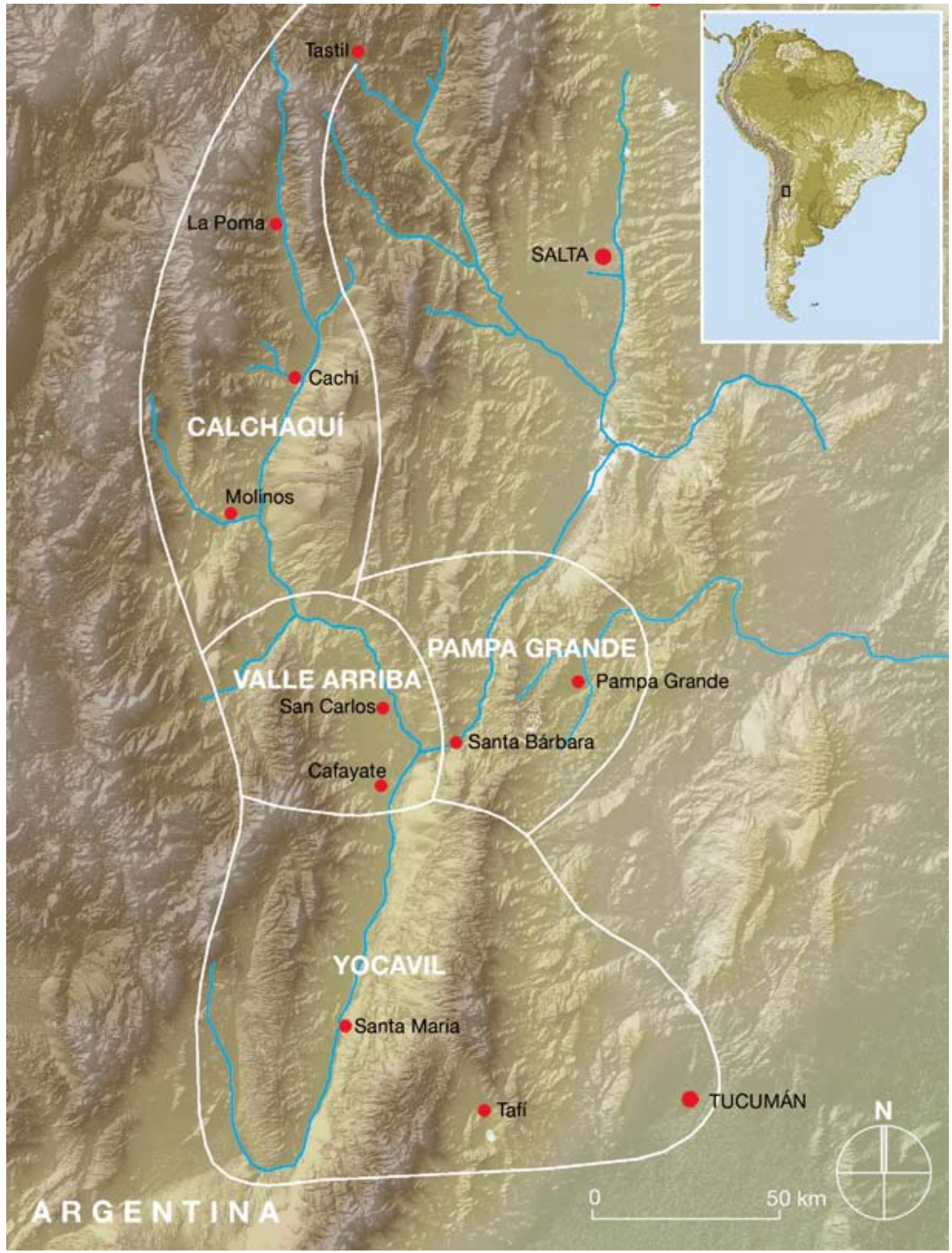

Figura 2. Área de estudio con indicación de la distribución de las subtradiciones regionales del estilo santamariano según Caviglia (1985)

Figure 2. Study area including the distribution of the Santamariano-style regional subtraditions according to Caviglia (1985). 
se representa también la boca de este modo, junto con el modelado de las mejillas.

Existe también correspondencia entre el cuerpo de este personaje antropomorfo central y el de la vasija, en un procedimiento metafórico en el que los marcos de referencia consisten en diferentes soportes materiales: imagen pintada y modelado cerámico. ${ }^{4}$ El elemento que más destaca es el vestido, que puede ser de dos tipos, aparentemente de acuerdo con el género del personaje en cuestión (Weber 1981: 19). Sólo uno de ellos permite que se vean los brazos, recogidos hacia el centro de la figura, ya sea solos o sosteniendo un puco. Estos son los únicos elementos del cuerpo que parecen realizados con pastillaje además de pintura.

En las urnas santamarianas no hay representación de los miembros inferiores. En el caso de las piezas en las cuales se organizó la decoración del cuerpo en base a una división tripartita vertical (Podestá \& Perrota 1973: 11), en la sección basal continúa casi siempre la representación pintada de la sección media (fig. 3). En cambio las piezas que tienen decoración del cuerpo con brazos (ya sean humanos o serpentiformes) presentan división entre las secciones media y basal de la vasija (Podestá \& Perrota 1973: 12). En esta última se dispone la misma decoración no figurativa habitual en los pucos, con los cuales comparten una misma identidad tecnológica y morfológica.

Hay una pequeña proporción de casos (5\%) en los que faltan casi por completo los elementos figurativos que refieren al personaje central de la pieza. ${ }^{5}$ Mucho

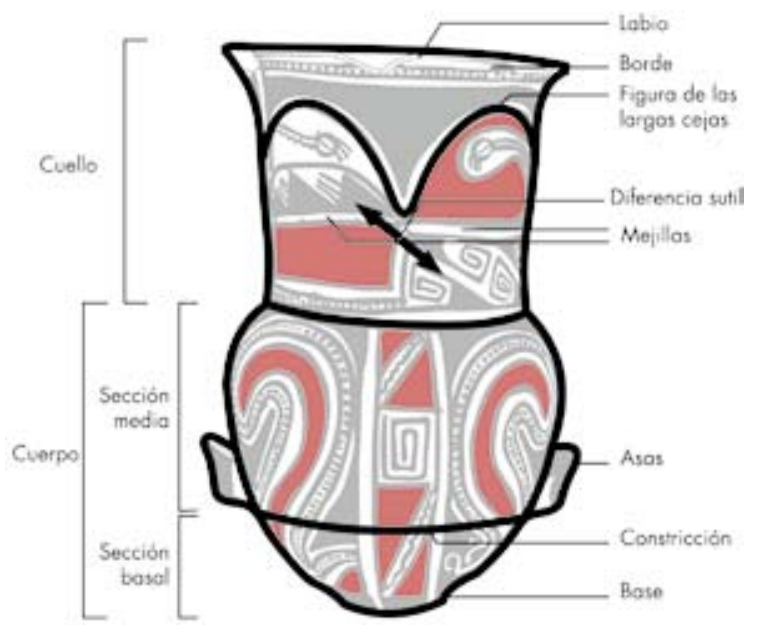

Figura 3. Secciones y partes constitutivas del género de las urnas santamarianas (modificado de Weber 1978). Se indica la manifestación de la diferencia sutil en la alteración de la simetría rotacional del cuello.

Figure 3. Constituent sections and parts of the Santamariana urn genre (modified from Weber 1978). The subtle alteration of the neck's rotational symmetry is marked. más excepcionales son los ejemplares en los que en una cara aparece representado dicho personaje y en la opuesta otra figura, pues en la gran mayoría de los casos las representaciones de ambas caras son prácticamente iguales, aunque siempre con alguna variación en detalles como la presencia diferencial de algún componente o cambios en la cantidad u orientación de un mismo elemento (fig. 3). Esta apelación a pequeñas diferencias, falsa simetría o gemelidad imperfecta (Lévi-Strauss 1992), que hemos dado en llamar diferencia sutil (Nastri 20052006), también se plantea entre los dos términos de la simetría en la decoración de una misma cara, ya sea en la decoración del cuello, la del cuerpo, o ambas.

En los primeros tiempos de desarrollo de la arqueología del Noroeste Argentino, las variaciones en el estilo de las urnas santamarianas fueron interpretadas en términos de variaciones locales a partir de una forma "típica" (Bregante 1926: 29) o clásica, propia del valle de Santa María. Por su parte, Sergio Caviglia (1985) -en un trabajo aún inédito- establece cuatro tradiciones regionales para el estilo santamariano: Yocavil, extendida por el valle de Santa María y el de Tafí; Calchaquí, en el valle homónimo; Santa Bárbara o Pampa Grande, a lo largo de la Quebrada de las Conchas, y Valle Arriba, en la zona de Cafayate, lugar de confluencia de las tres tradiciones anteriores (figs. 2 y 4).

El esquema de representación básico de las urnas se mantiene constante en la gran mayoría de los ejemplares. De esto se desprende que la representación no constituye una expresión de la inspiración particular de un artista individual sino que responde a un patrón extendido en la sociedad (por ejemplo, mitos) y, por lo tanto, con un valor especial probablemente articulado con disposiciones propias de la organización política o social del grupo. Las líneas fundamentales de dicho patrón están dadas por la disposición de los campos decorativos en función de las partes de la vasija, como metáfora de una forma humana o semihumana (González, A. R. 1977: 323), cuyo rasgo más notorio y compartido es el rostro.

\section{LA INTERPRETACIÓN DE LAS IMÁGENES}

Para la comprensión de estilos y géneros resulta útil la discriminación entre rasgos temáticos, retóricos y enunciativos (Steimberg 1993). La dimensión temática está dada por la referencia de un texto a "acciones y situaciones según esquemas de representabilidad históricamente elaborados y relacionados, previos al texto" (Segre 1985: 48); la retórica, por los mecanismos de configuración de un texto (Hodder 1993), mientras que la enunciativa 


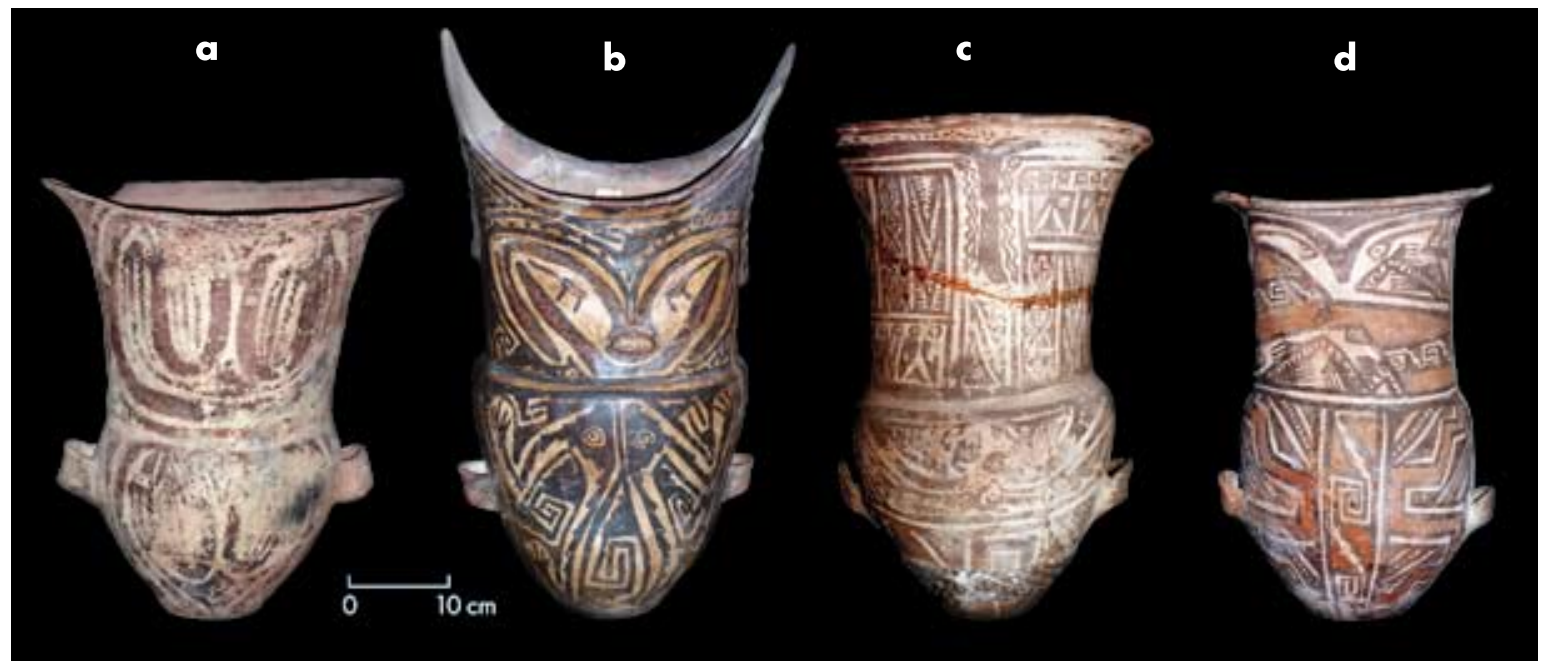

Figura 4. Variantes regionales de las urnas santamarianas establecidas por Caviglia (1985). De izquierda a derecha: a) Calchaquí; b) Pampa Grande; c) Valle Arriba; d) Yocavil.

Figure 4. Regional variants of the Santamariana urns, established by Caviglia (1985). From left to right: a) Calchaqui; b) Pampa Grande; c) Valle Arriba; d) Yocavil.

alude a las condiciones de la situación comunicacional. ${ }^{6}$ La primera y la última constituyen las dimensiones más difíciles para los abordajes arqueológicos. Los esquemas de representabilidad previos al texto, en el marco de sociedades sin escritura, prácticamente pueden conocerse sólo en el caso de tiempos no muy lejanos, cuando han podido conservarse tradiciones orales o crónicas del tiempo del contacto. Las condiciones de la situación comunicacional son posibles de ser reconstruidas por medios exclusivamente arqueológicos y a partir de un registro muy amplio y detallado, algo que recientemente ha tomado impulso en la arqueología calchaquí en relación a los contextos mortuorios (Johansson 1996; Marchegiani 2008). ${ }^{7}$ En la consideración de los rasgos temáticos, dos herramientas clave son los conceptos de tema y motivo. Panofsky asimila los motivos a los significados primarios o naturales y los temas a los significados secundarios o convencionales (motivos + conceptos). Además, este autor toma en cuenta el significado intrínseco o contenido, aludiendo con éste a los valores más generales expresados a través de la representación (Panofsky 1983: 47-49).

Para ejemplificar, podemos tomar la representación del ñandú o suri a la manera de significado primario: una determinada configuración de líneas y de colores permite identificar a dicho animal de manera clara (fig. 5, pieza Fase II), en el contexto de lo que Panofsky denomina análisis preiconográfico. Esta interpretación de significados primarios comprende un aspecto fáctico (el ñandú) y un contenido expresivo (por ejemplo

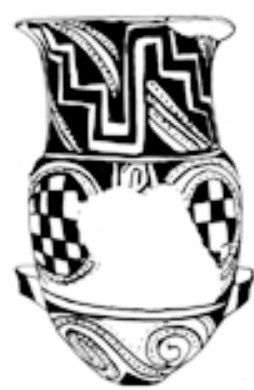

Fase 0

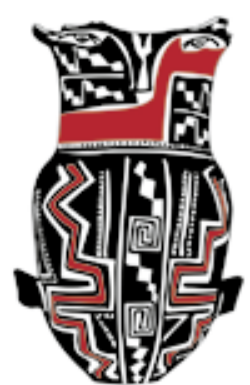

Fase I

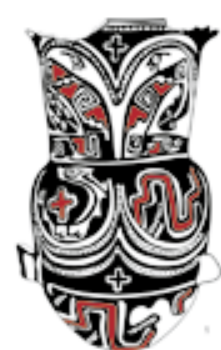

Fase II
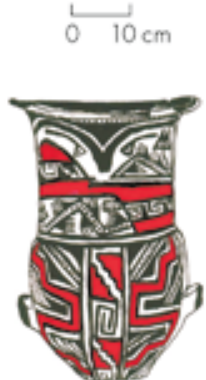

Fase III

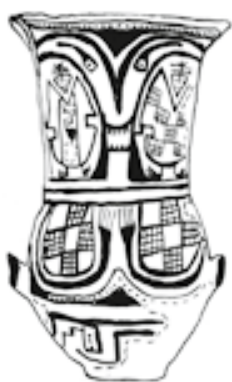

Fase IV

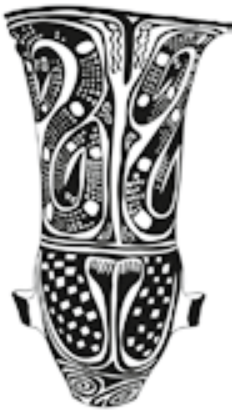

Fase V

Figura 5. Secuencia de fases de las urnas santamarianas clásicas o variedad Yocavil, desarrollada por Weber (1978) y Podestá y Perrota (1973). Los ejemplos usados pertenecen a ejemplares de la muestra trabajada en la presente investigación.

Figure 5. Developmental phases of the classic Santamariana urns, or Yocavil variety, by Weber (1978) and Podestá and Perrota (1973). The examples used include samples from the current study's collection. 
el ñandú apacible, inquieto o a la carrera) (Panofsky 1979: 14). El tema en el cual este motivo se encuentra articulado ya corresponde a un segundo nivel de mayor abstracción que, por lo tanto, requiere una carga interpretativa también mayor. En el caso que nos ocupa, los autores de principios del siglo xx no dudaron en asociar la figura del ñandú con el tema de la lluvia y la fertilidad (Quiroga 1992: 432). ${ }^{8}$ Más allá del acuerdo o no con esta interpretación, me interesa señalar el valor del motivo como el elemento más claramente identificable y que permite sentar bases para la comparación de la evidencia. Para esto debe tenerse en cuenta que:

Temas y motivos cumplen [...] una labor de formalización [...] en segmentos de diversa medida y a diferentes niveles, y es esta formalización la que simplifica y acelera la comprensión del discurso de las ideas, ya que suministra pequeños bloques compactos de realidad existencial o conceptual estructurada semióticamente (Segre 1985: 357).

La articulación de motivos y temas, en el marco de historias y alegorías, conlleva a la realización del análisis iconográfico propiamente dicho; antesala de la síntesis interpretativa que Panofsky (1983: 49) denomina iconología y que consiste en el descubrimiento del significado intrínseco o contenido, la "mentalidad básica" de una sociedad, manifiesta tanto en la significación iconográfica como en los procedimientos de composición. El problema con los objetos del pasado precolombino de la región reside en que las "historias y alegorías" o bien están ausentes, o bien persisten muy fragmentadas y mezcladas con tradiciones posteriores. Por ejemplo, en Costumbres y supersticiones en los valles calchaquies, Ambrosetti (1953: 117) documentó varias prácticas, ritos y creencias, destacando siempre el hecho de que la superposición de "otros hombres y otras civilizaciones” a lo largo del tiempo pudo haber alterado su forma primitiva, la cual tenía más posibilidades de conservarse intacta hacia el sur. ${ }^{9}$

\section{ROSTROS EN LAS VASIJAS}

Al sur de nuestra área de estudio, en la actual provincia argentina de La Rioja, Agüero Vera documentó la veneración de otras divinidades de carácter maléfico o bien dual, como la Yacumama, quien era buena de día y mala de noche. Yacumama significa "madre del agua" y su rasgo principal estaba dado por sus "grandes ojos blancos y fosforescentes" (Agüero Vera 1972: 60). ${ }^{10} \mathrm{~A}$ comienzos del siglo xx se representaba a la Yacumama en las zonas serranas de La Rioja como una viejecita toda blanca, que moraba cerca de los manantiales. Señala Agüero Vera (1972: 64) que este culto se encontraba muy relacionado con la serpiente, dado que ésta era una de las formas que adoptaba la diosa para asustar a todo aquel que osara acercarse a su morada una vez caído el sol.

Los ojos de la figura de las largas cejas resultan altamente llamativos al observador. Por lo general están trazados en color negro y no son de gran tamaño, a diferencia de las cejas, que sí presentan grandes proporciones. No obstante, en la muestra considerada existe una cantidad de casos (30) que por sobre los ojos "habituales" presentan otro par, de mayor tamaño y realizado en negativo, de modo que resaltan en color blanco, de una manera similar a la de los "ojitos" de la decoración arquitectónica calchaquí (Reynoso 2003) y a la descripción de la divinidad recopilada por Agüero Vera. La pieza de la figura 6 constituye un caso notable de definición del motivo que hemos denominado sobre-rostro negativo y que se forma a partir de la combinación de dos elementos: las cejas compuestas por líneas de triángulos unidos y un tumi o triángulo curvado superior (Nastri 1999: 392, 395-396) con una punta gruesa rectangular. La boca de la urna pareciera tener mayor vinculación con el sobre-rostro, de nariz triangular negativa y de aspecto felínico, que con el rostro "habitual" de la figura de las largas cejas, indicado por ojos-cabeza-de-ñandú incluidos en una franja roja en forma de "V" que atraviesa todo el cuello.

En la pieza de la figura 7 el motivo presenta también una muy buena definición, pero, a diferencia de la anterior, el triángulo negativo que representa la nariz está orientado con un vértice en la parte superior y un "cateto" horizontal en la inferior. Pero lo más interesante de esta pieza es que el sobre-rostro presenta en ambas caras de la vasija "largas cejas" de cordón punteado (Nastri 1999: 392), mientras que aquel que suponemos el rostro habitual tiene en una cara de la pieza cejas de cordón punteado y en el anverso un cordón negativo.

En lo que respecta a las bocas, por lo general sólo hay una por cara y en la mayoría de los casos no queda claro a cuál de los dos rostros corresponde, si es que es exclusiva de alguno. En ejemplares como el de la figura 8, por ejemplo, las bocas están adosadas a la parte inferior de los sobre-rostros y separadas de los ojos de la figura de las largas cejas por sendas líneas o campos divisorios (por lo general rojos). Pero en otros casos similares, como el de la figura 9, la división es más difusa o directamente queda de manifiesto la vinculación de la boca con el rostro habitual de la figura de las largas cejas. Y en casos como el de la figura 10 la boca se encuentra adosada al extremo inferior de las cejas de cordón punteado; los ojos de la figura de las largas cejas se encuentran enmarcados en la franja roja 


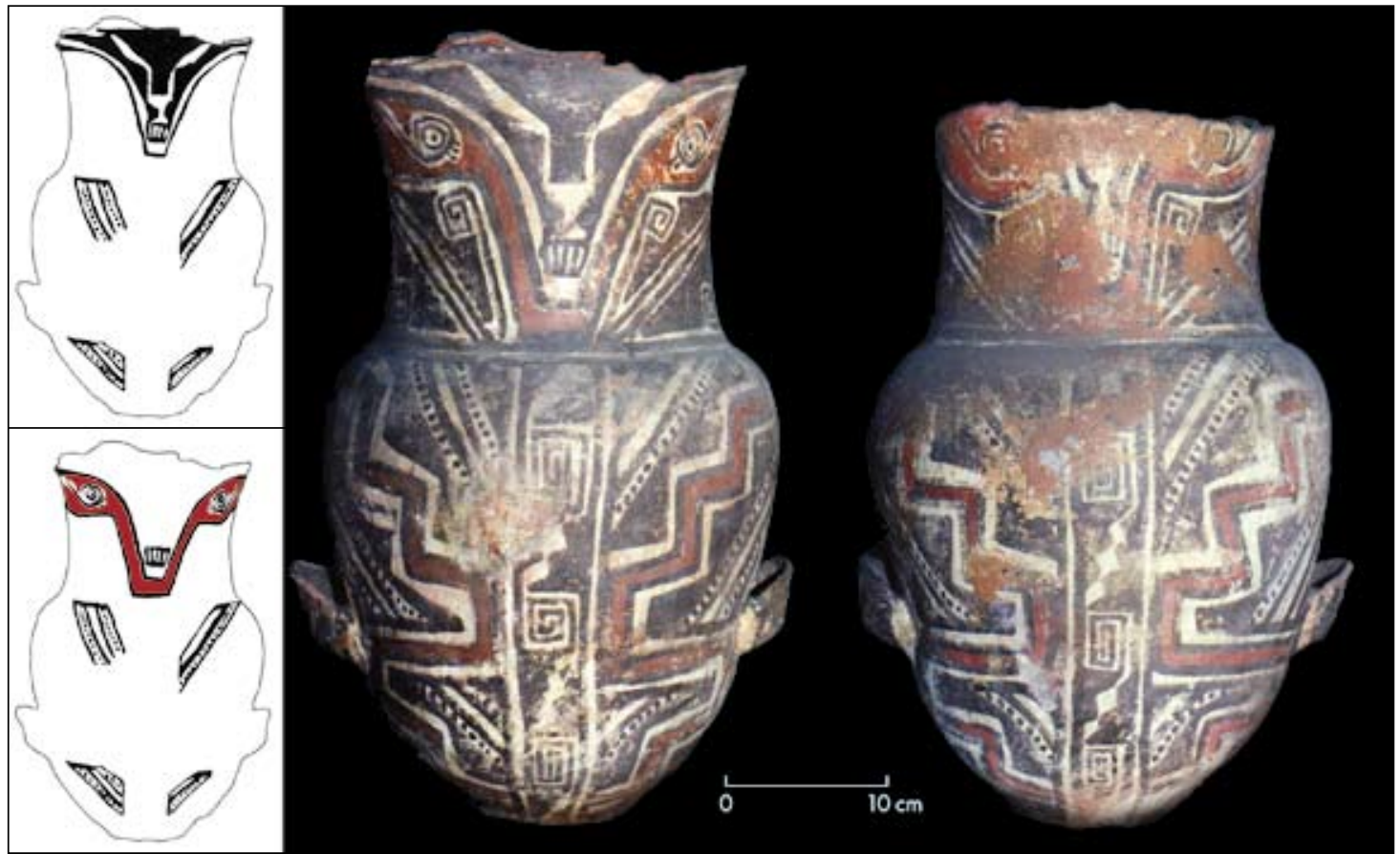

Figura 6. Ejemplo de sobre-rostro negativo. Pieza No 73-257 del Museo Etnográfico J. B. Ambrosetti (MEJBA), de la Universidad de Buenos Aires. En los recuadros se presentan el motivo de sobre-rostro y de rostro habitual del anverso de la pieza, en forma aislada. Del mismo modo se representan los motivos (en este caso, indiformes) donde se manifiesta la diferencia sutil. Figure 6. Example of negative negative resist face cover decoration. Piece No 73-257, Museo Etnográfico J. B. Ambrosetti (MEJBA), Universidad de Buenos Aires. The two boxes on the left present the face cover motif and the customary face motif on the piece's obverse side. In addition, they show other motifs (in this case, indiform) exhibiting subtle differences.

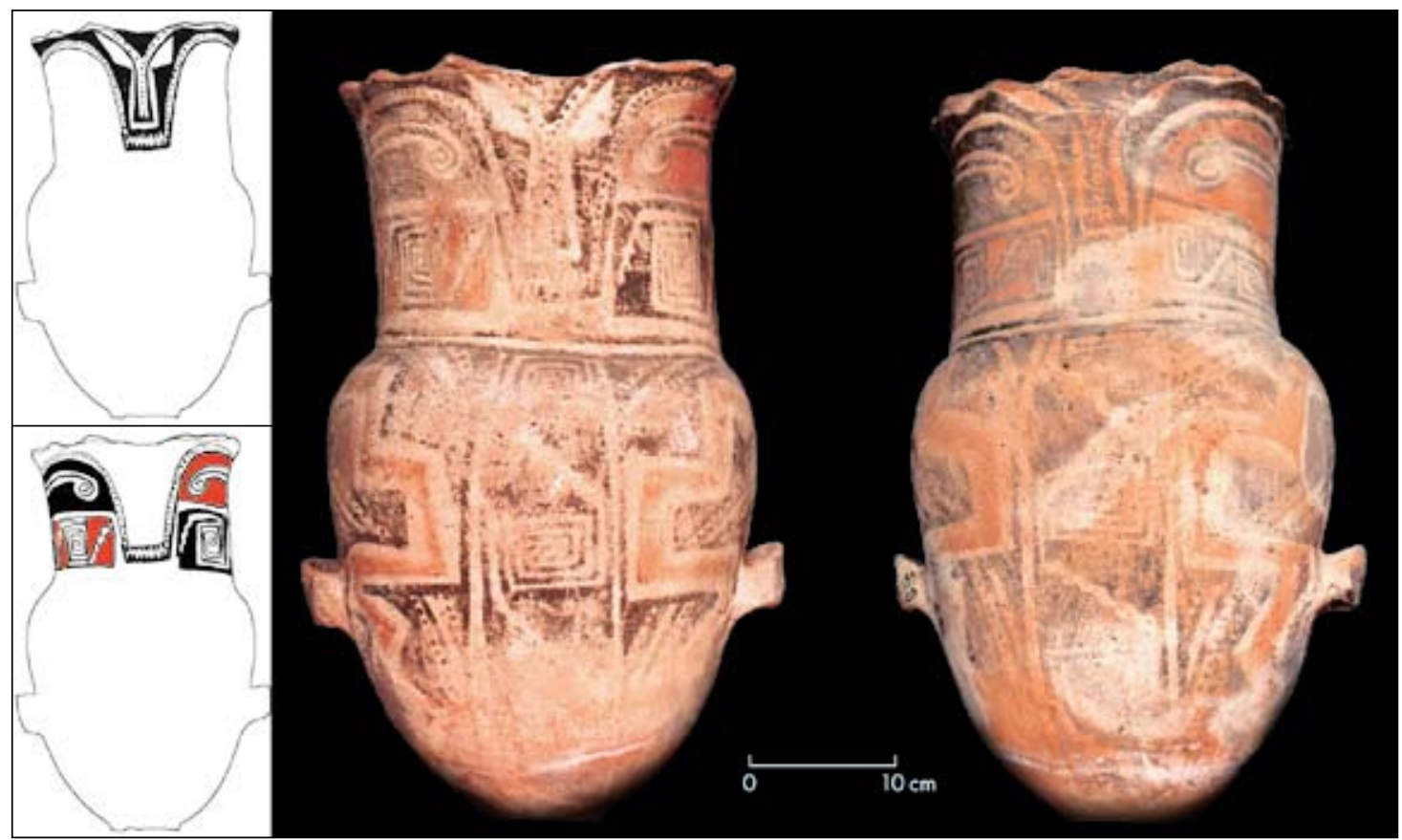

Figura 7. Ejemplo de sobre-rostro negativo. Pieza No 199 del Museo Arqueológico Provincial Eric Boman (MAPEB), de la ciudad de Santa María, Provincia de Catamarca. En los recuadros se presentan el motivo de sobre-rostro y de rostro habitual del anverso de la pieza, en forma aislada.

Figure 7. Example of negative resist face cover decoration. Piece No 199, Museo Arqueológico Provincial Eric Boman (MAPEB), Santa Maria, Province of Catamarca. The two boxes on the left present the face cover motif and the customary face motif on the piece's obverse side, without the rest of the decoration. 


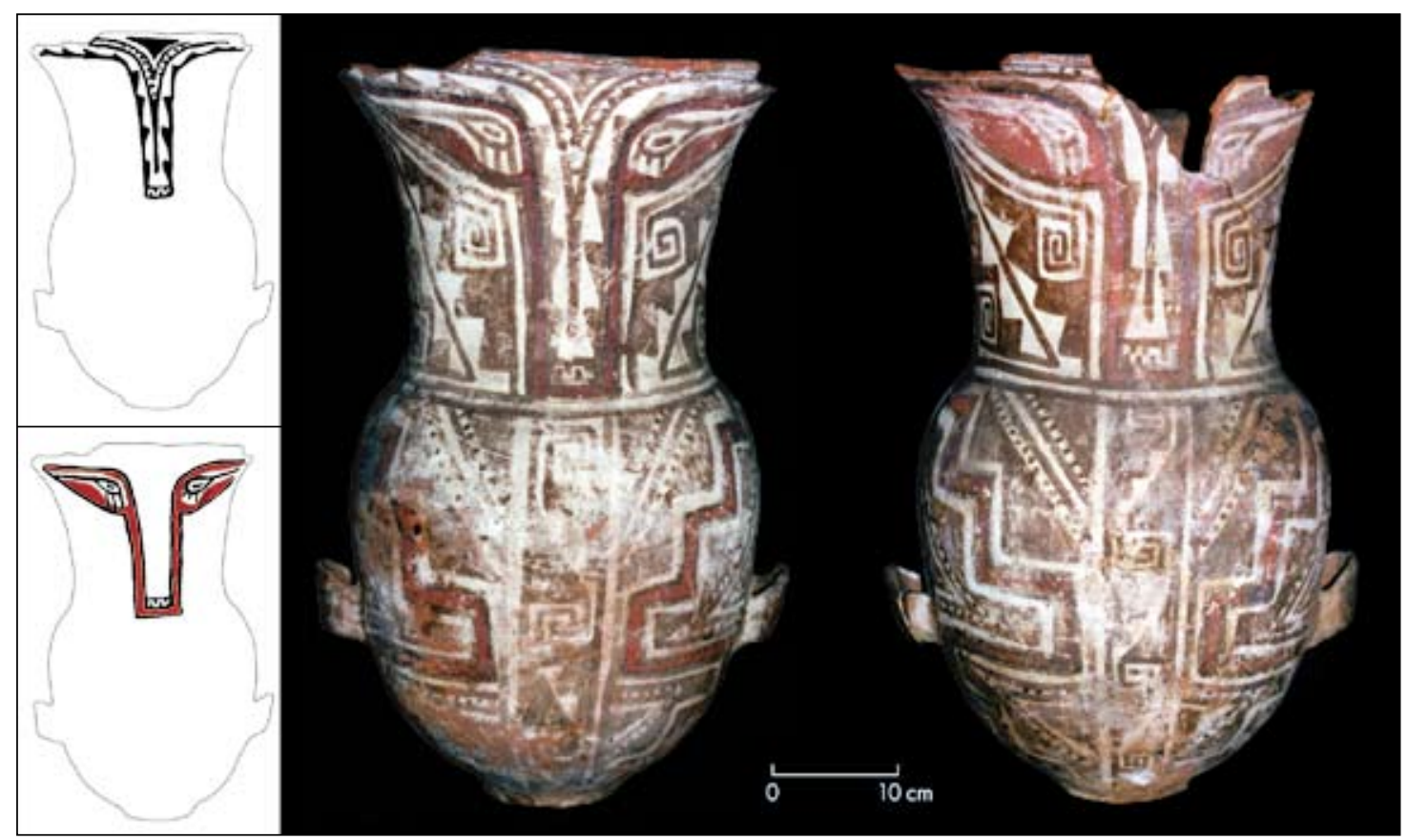

Figura 8. Ejemplo de sobre-rostro negativo. Pieza No VC5912 del Ethnologisches Museum (EM), de Berlín. Procedencia: Fuerte Quemado (colección Zavaleta). En los recuadros se presentan el motivo de sobre-rostro y de rostro habitual del anverso de la pieza, en forma aislada.

Figure 8. Example of negative resist face cover decoration. Piece No VC5912, Ethnologisches Museum (EM), Berlin. Source: Fuerte Quemado (Zavaleta collection). The two boxes on the left present the face cover motif and the customary face motif on the piece's obverse side, without the rest of the decoration.

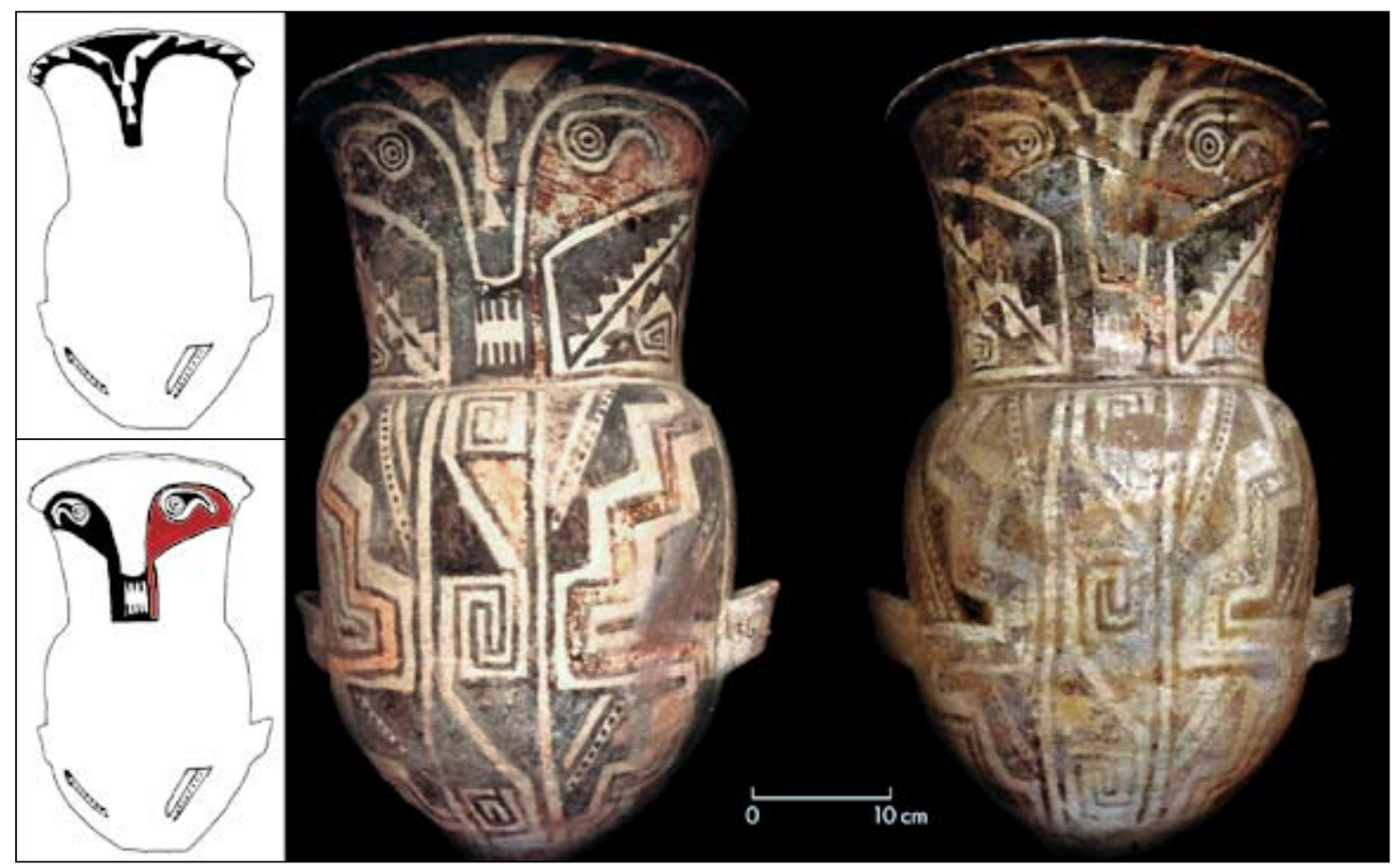

Figura 9. Ejemplo de sobre-rostro negativo. Pieza No 3 o 55/78 (MAPEB). En los recuadros se presentan el motivo de sobre-rostro y de rostro habitual del anverso de la pieza, en forma aislada. También se representan los motivos indiformes donde se manifiesta la diferencia sutil.

Figure 9. Example of negative resist face cover decoration. Piece $N^{\circ} 3$, or 55/78 (MAPEB). The two boxes on the left present the face cover motif and the customary face motif on the piece's obverse side. In addition, they also show other motifs (in this case, indiform) exhibiting subtle differences. 


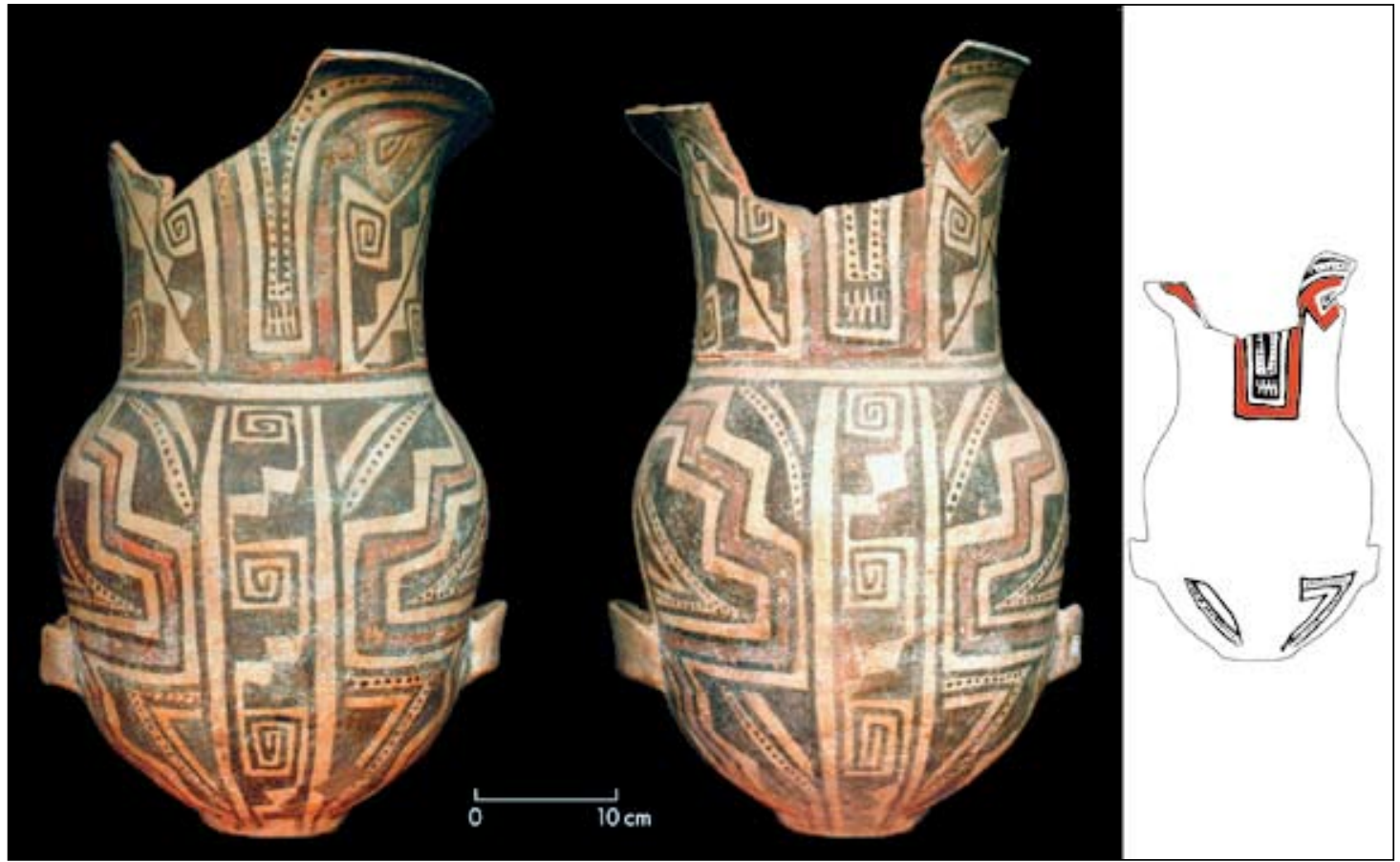

Figura 10. Ejemplo de decoración similar a la de sobre-rostro negativo, pero sin presencia evidente del mismo. Pieza No 36 (MAPEB). En el recuadro se presenta el motivo del rostro de la figura de las largas cejas en el reverso de la pieza, en forma aislada. Del mismo modo se representan los motivos indiformes donde se manifiesta la diferencia sutil.

Figure 10. Example of decoration similar to that of the negative resist face cover, but without the face cover's readily apparent presence. Piece $N^{o} 36$ (MAPEB). Inset: the face of the long-eyebrowed figure on the piece's back side. Also shown are indiform motifs exbibiting subtle differences.

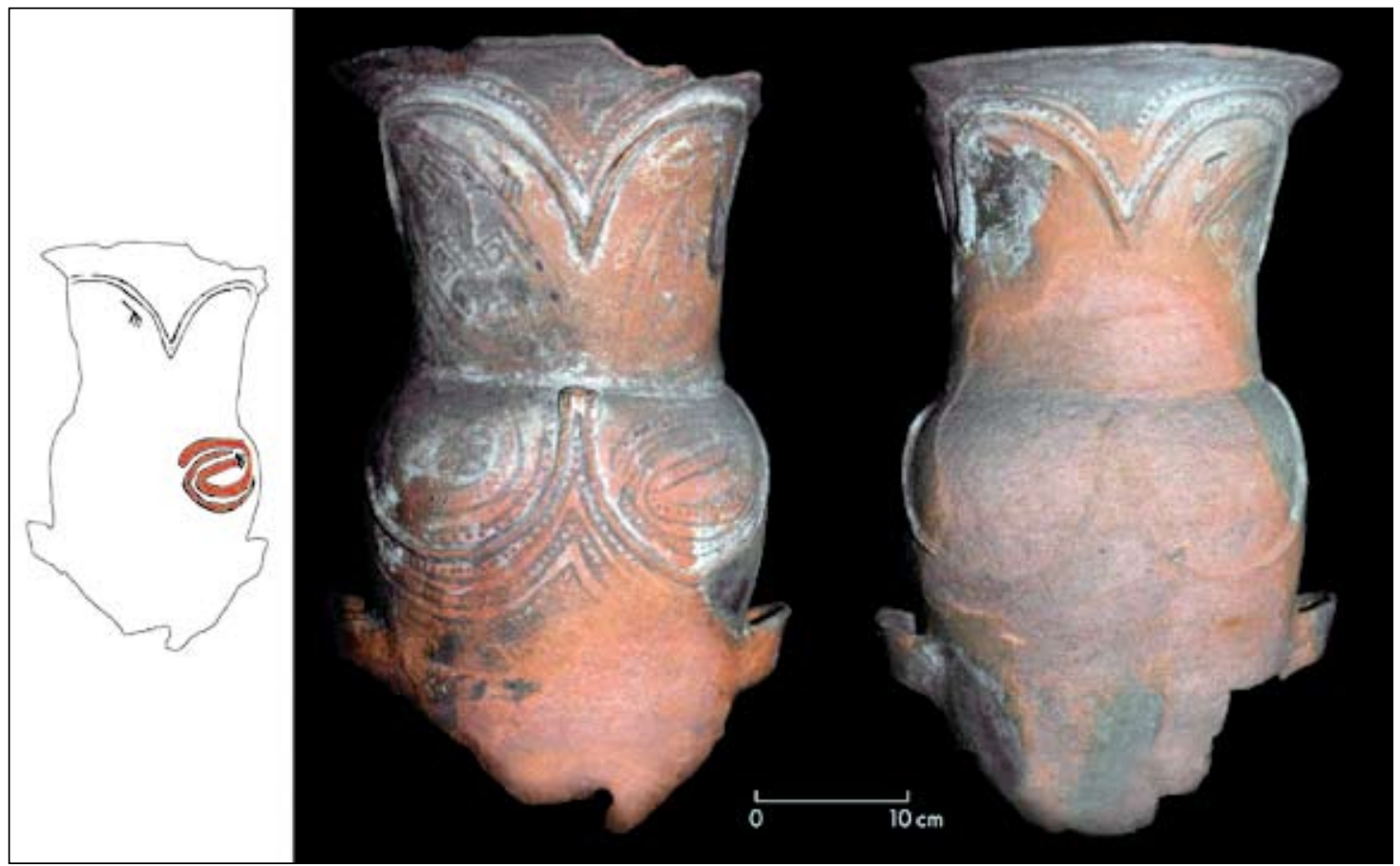

Figura 11. Ejemplo de rostro de la figura de las largas cejas con ojos cerrados y decoración de serpientes curvas en el cuerpo. Pieza $\mathrm{N}^{\mathrm{o}}$ 73-233 (MEJBA).

Figure 11. Example of the face of the long-eyebrowed figure, with eyes closed, and of the decoration of undulating serpents on the personage's body. Piece $N^{\circ} 73-233$ (MEJBA). 
en forma de "V", pero no hay sobre-rostro, sólo está el espacio negativo entre las cejas y la franja roja.

Cabe destacar que todos los casos de sobre-rostros identificados corresponden a piezas con decoración tripartita del cuerpo; esto es, que tienen la decoración del cuerpo organizada en función de una banda central vertical (Nastri \& Vietri 2004: 368). Esta presencia diferencial resalta el carácter significativo de la oposición entre los dos tipos de organización del cuerpo (véase siguiente acápite), en lo que respecta a la figura de las largas cejas. ${ }^{11}$ Quiroga, quien le ha prestado gran atención, se preguntaba:

[...] ¿esta figura general, al parecer de rostro humano, de vientre abultado, de largos brazos, y cuyas manos portan el vaso, es en realidad una figura ó representación antropomorfa? Contestaremos negativamente. [...] La figura ó representación en cuestión tiene á la vez caracteres humanos y animales (Quiroga 1901: 135-136)

Resultaban "humanos" para Quiroga el corte de la cara, los arcos de las cejas y la boca dentada; mientras que los ojos (cabezas de ñandúes o de serpientes) y la nariz (alargada como continuación de las cejas en forma de pico de ave) aluden a especies animales. De acuerdo a lo propuesto por Panofsky (1979: 14), resulta útil considerar no sólo el aspecto fáctico (ojo humano, de ñandú, de serpiente, etc.) sino también el expresivo, para fines de la interpretación de los significados primarios. El ojo de la figura de las largas cejas se representa en algunas ocasiones con la apariencia de estar cerrado (fig. 11), pero más frecuentemente como cabeza de ñandú.

Como parece ser regla en el arte santamariano, con las alteraciones y permutaciones entre motivos a lo largo de la serie (Nastri 2008), existe un espectro de grados en la claridad de la asignación: desde aquellos casos bien evidentes, hasta los más ambiguos. Entre los primeros cabe destacar los casos en que los ojos de la figura de las largas cejas corresponden a la vez a las cabezas de sendos ñandúes naturalistas (estilizados en volutas o no) que ocupan cada una de las mejillas (fig. 12); entre los más ambiguos se cuentan casos de ojos circulares, con largos apéndices curvos (¿cuellos de ñandú?), pero sin que se pueda reconocer el cuerpo del animal en la decoración del cuello de la vasija (véase fig. 3). En un grado intermedio de ambigüedad se encuentran los casos de ojos realizados en términos de dos círculos concéntricos bien redondos: el externo haría entonces simultáneamente de cabeza de ñandú y de órbita del ojo de la figura de las largas cejas; el círculo interior haría de órbita del ojo del ñandú y de iris del ojo de la

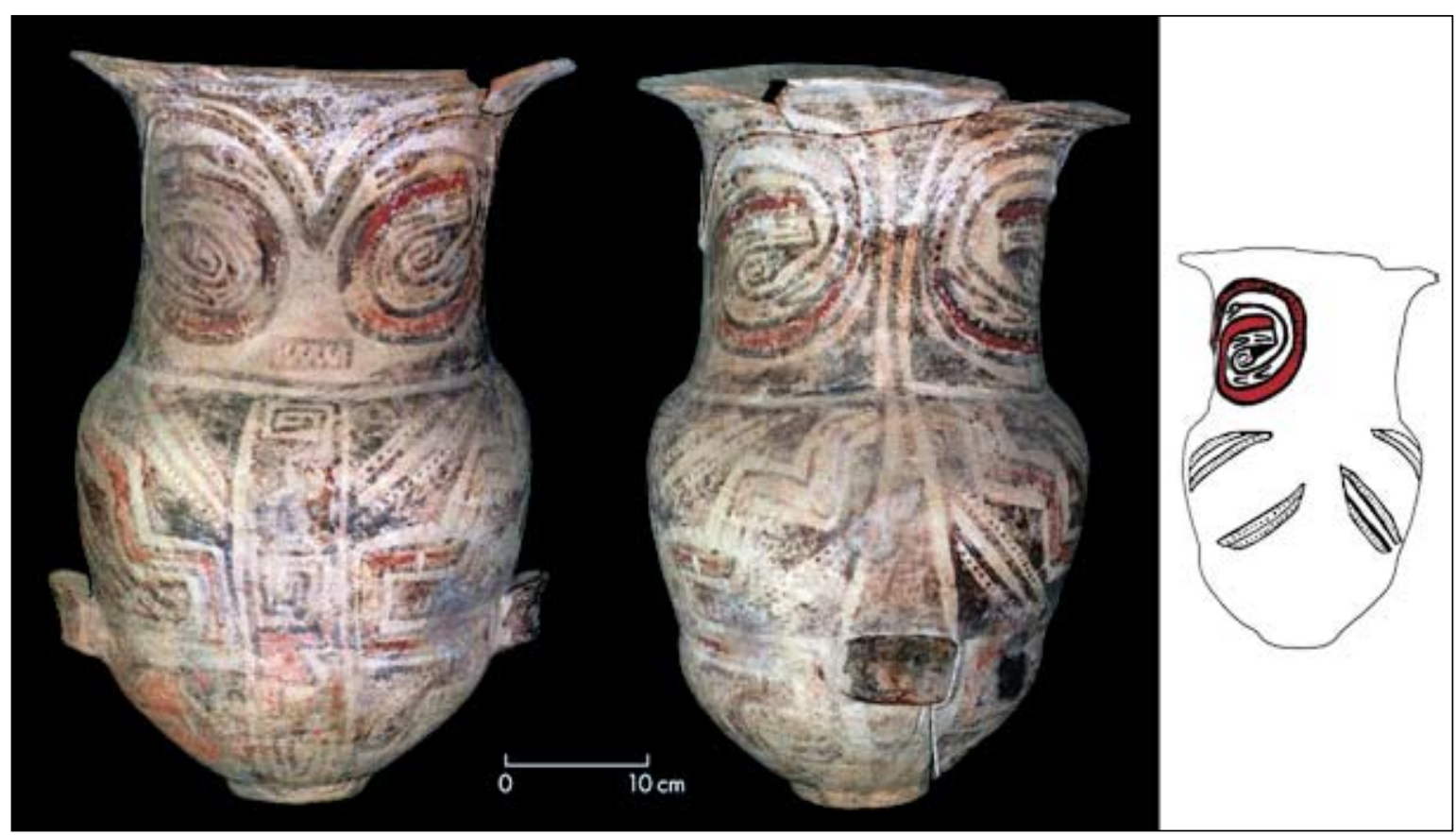

Figura 12. Ejemplo de ojos de la figura de las largas cejas, conformados por una representación bipartida de ñandúes estilizados en volutas. Pieza No 4554 del Museo de La Plata (MLP). Procedencia: El Bañado (colección Muñiz Barreto). En el recuadro se presenta el motivo del ñandú en forma aislada, junto con los motivos indiformes donde se manifiesta la diferencia sutil.

Figure 12. Example of the long-eyebrowed figure's eyes, formed by a two, symmetrical ñandu (Rhea americana) representations, stylized as volutes. Piece No 4554, Museo de La Plata (MLP). Source: El Bañado (Muñiz Barreto collection). Inset: the ñandú motif, together with indiform motifs exhibiting subtle differences. 
figura de las largas cejas; por último, un punto negro haría de pupila del ojo de la figura de las largas cejas y de ojo del ñandú (figs. 6 y 9). ${ }^{12} \mathrm{El}$ diseño de ojos en forma de círculos concéntricos ha sido señalado ya en el arte prehispánico del NOA, para períodos previos de la etapa agroalfarera, como representativo de estados alterados de conciencia (Gordillo 1990: 23). Lo que puede apreciarse en los casos mencionados es que dicha forma de representación de los ojos de la figura de las largas cejas está siempre asociada a piezas con sobre-rostro negativo.

$\mathrm{El}$ aspecto expresivo de la figura de las largas cejas no está centrado sólo en los ojos, sino también en la boca. El rostro adquiere una expresión amenazante cuando los ojos con apéndices de líneas dispuestos por encima en orientación vertical se combinan con una boca con indicación de dientes, curvada hacia arriba, como es norma en las urnas Fase IV (figs. 5, 13,14 y 15). Se puede apreciar entonces que la figura de las largas cejas representa un ser que en ocasiones puede ser amenazante y en otras no. Y la expresión puede radicar en ella o bien en un ser fantástico que está por detrás; ya sea que este ser se "coma" a la figura de las largas cejas; que represente al alter ego o animal tutelar del chamán (Llamazares 2004: 100-102) o a un atuendo cefálico de éste, que le transmitiera las propiedades agresivas del animal, en la manera usual en que se viste el sacrificador en diversas sociedades de los Andes y la Amazonia (González, A. R. 1998: 208). La pieza modelada de la figura 16 , aunque del período anterior al que nos ocupa, constituye un buen ejemplo al respecto.

\section{REPRESENTACIONES DE TIPO SACRIFICIAL EN LAS MEJILLAS DE LAS URNAS}

Como también ilustra la pieza Aguada de la figura 16, desde tiempos anteriores al Período Tardío en la Subárea Valliserrana se representaba a figuras humanas con decoración facial en diferentes soportes, incluyendo vasijas con rostros modelados y motivos grabados o pintados sobre los mismos. En la alfarería Condorhuasi, Ciénaga y Aguada existe un gran número de ejemplos de personajes que presentan decoración en sus mejillas (González \& Pérez 1972; González, A. R. 1998). Si bien hay casos (sobre todo en el Período Medio, con técnica grabada sobre vasos modelados) en los cuales la decoración (un animal de perfil, o en representación bipartida, por ejemplo) parece "sobreimponerse" al rostro sin relación aparente con la "topografía" del mismo (p. e. González, A. R. 1998: 200-205), casi siempre la decoración se articula con los rasgos faciales, disponiéndose muy frecuentemente sobre campos definidos y delimitados, tales como la frente y las mejillas. El arte santamariano le imprimió un fuerte énfasis a esta concepción, popularizando en sus primeras fases las mejillas ocupadas por motivos encerrados en formas curvas (ovales), generalmente con presencia de pintura roja. Uno de los motivos representativos de esta forma de decoración de las mejillas es el de los ñandúes scroll (Weber 1978: 59) o estilizados en forma de voluta (Perrota \& Podestá 1974), los cuales presentan un cordón rojo a modo de borde del cuerpo, que a su vez se transforma en ceja

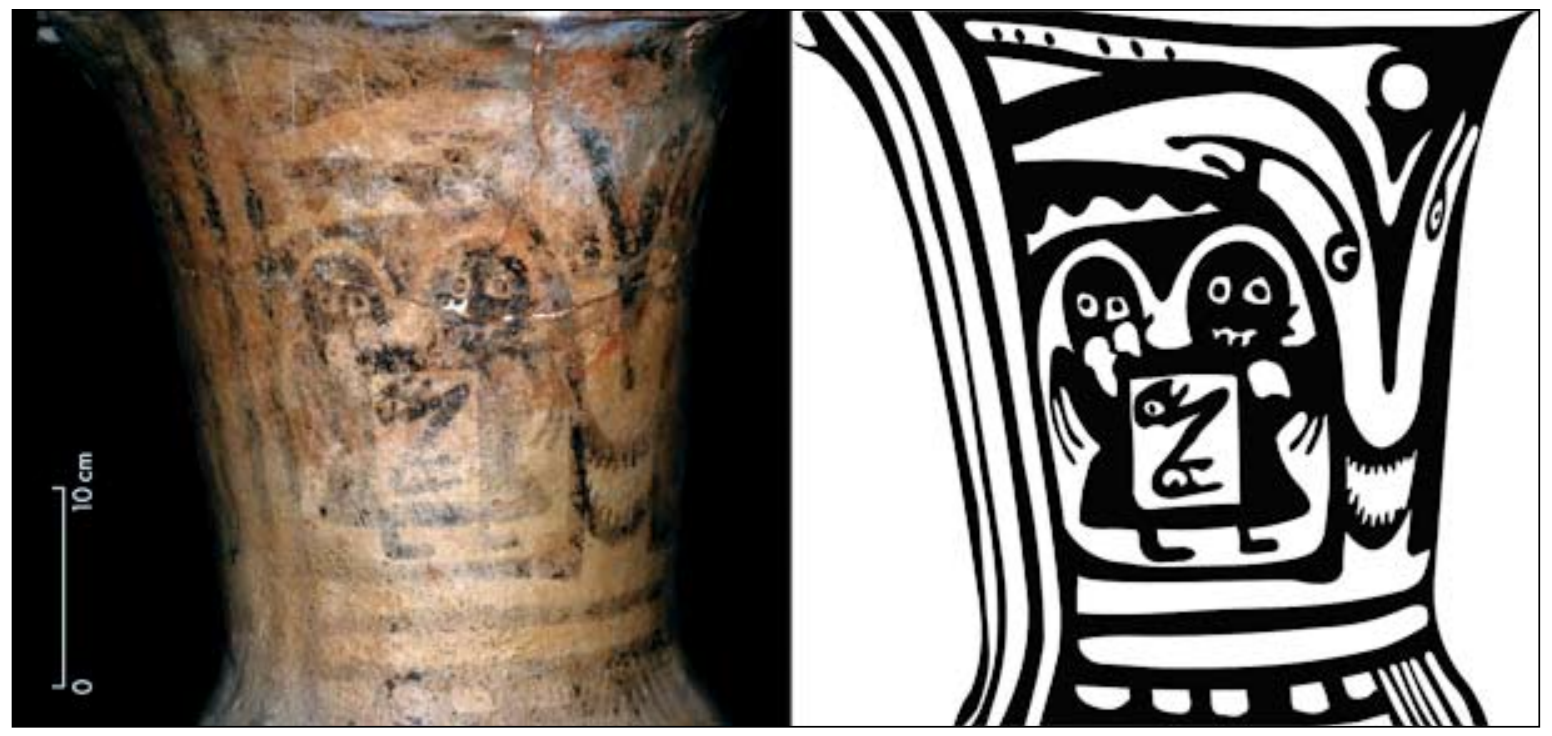

Figura 13. Representaciones de sacrificadores-sacrificados en el cuello de la urna No 2540 (MLP, colección Moreno). Figure 13. Representations of sacrificers/the sacrificed on the neck of urn $N^{\circ} 2540$ (MLP, Moreno collection). 
de la figura central y nuevamente en borde de cuerpo de ñandú en la mejilla opuesta (véase fig. 12).

Hay casos en los cuales resulta evidente que el tamaño de las figuras circulares "ha crecido", al punto de ocupar hasta los límites mismos del cuello por los costados y en su parte inferior, confundiéndose con el borde de los campos decorativos en la garganta de la pieza. De esta manera, no se trata ya de motivos circulares en las mejillas, sino de mejillas delimitadas y llenas de motivos en todo su interior. La mejilla delimitada deja libre al rostro de la figura de las largas cejas -la cual puede considerarse también en forma separada de las mejillas, como un rostro angosto en forma de "Y", remarcando quizás con esta extraña forma un estatus semibumano- y ocupa toda la porción aproximadamente triangular que se extiende desde la altura de los bordes externos de la banda central del cuerpo de la vasija hasta el borde lateral superior del cuello (figs. 13, 14 y 15). Los motivos denominados "guerreros" (Podestá \& Perrota 1973; Weber 1978) se corresponden con la estructura de diseño de mejillas delimitadas en el cuello, donde éstas adquirieron una forma definida de cuasi-triángulo recto con una línea curva convexa hacia el centro de la pieza en lugar de la hipotenusa. Estos personajes se pueden manifestar ataviados con túnicas o protegidos por escudos, variantes que presentan idéntica proporción en la muestra. ${ }^{13}$

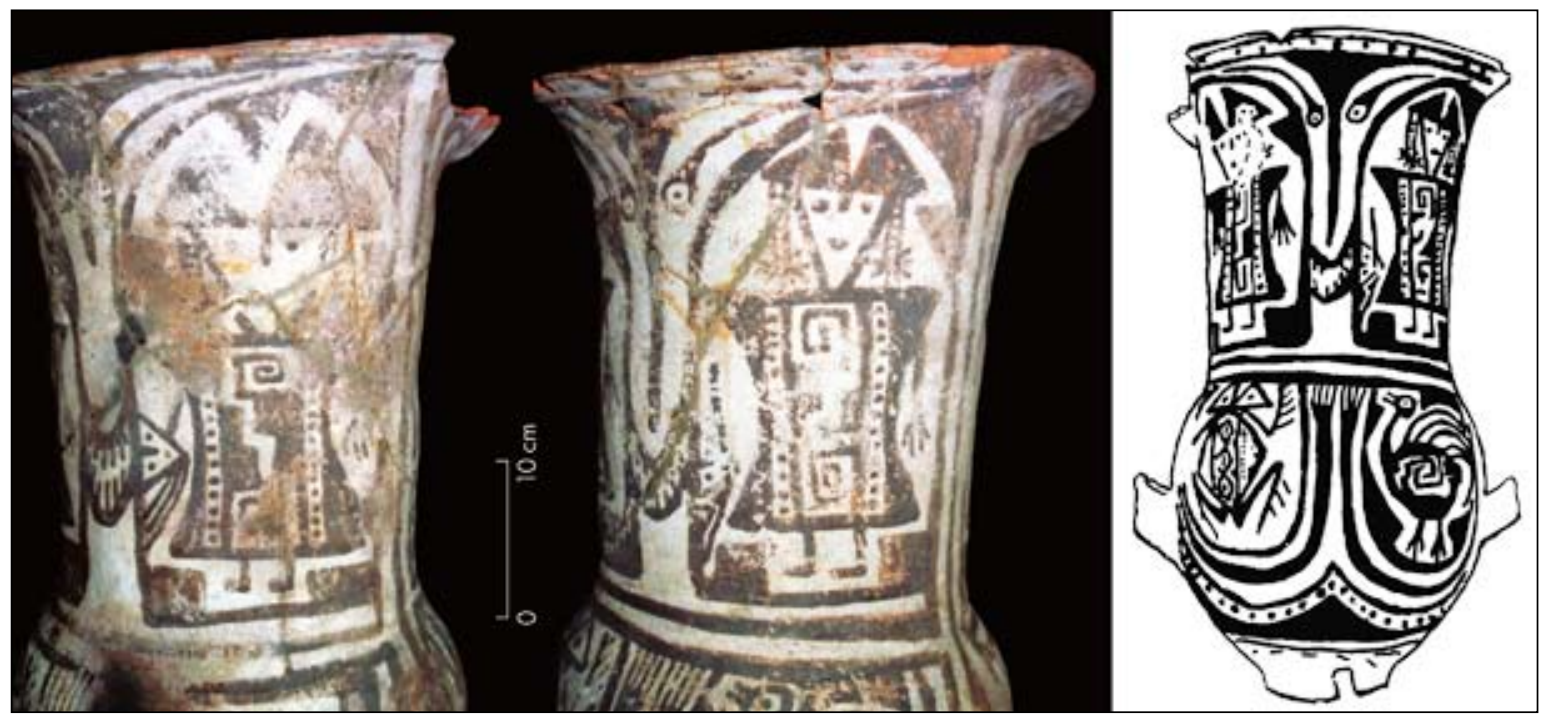

Figura 14. Representación de cabezas trofeo en las mejillas de la urna No VC6494 (EM). Procedencia: Fuerte Quemado (colección Zavaleta).

Figure 14. Trophy heads representation on the cheeks of urn $N^{\circ}$ VC6494 (EM). Source: Fuerte Quemado (Zavaleta collection).

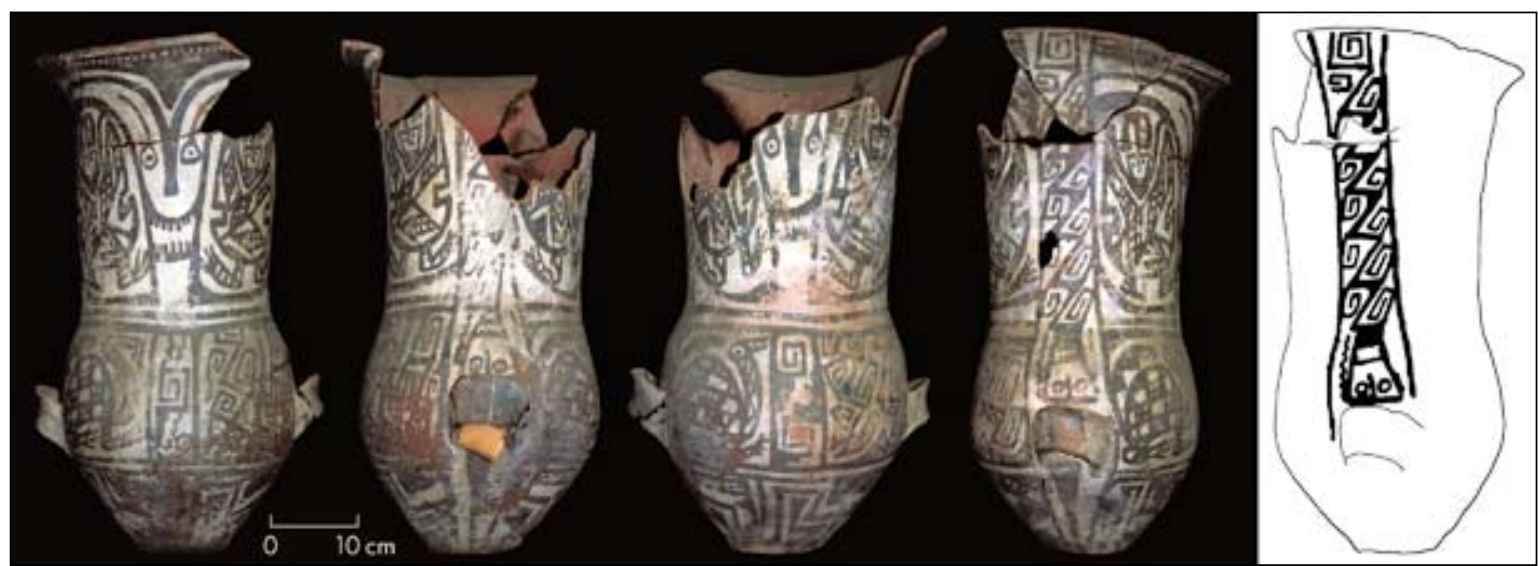

Figura 15. Representación de cabezas trofeo en las bandas laterales de la urna No 5968 (MLP), procedente de Lorohuasi, provincia de Catamarca (colección Muñiz Barreto).

Figure 15. Trophy head representations on the lateral bands of urn $N^{\circ} 5968$ (MLP), from Lorohuasi, Province of Catamarca (Muñiz Barreto collection). 

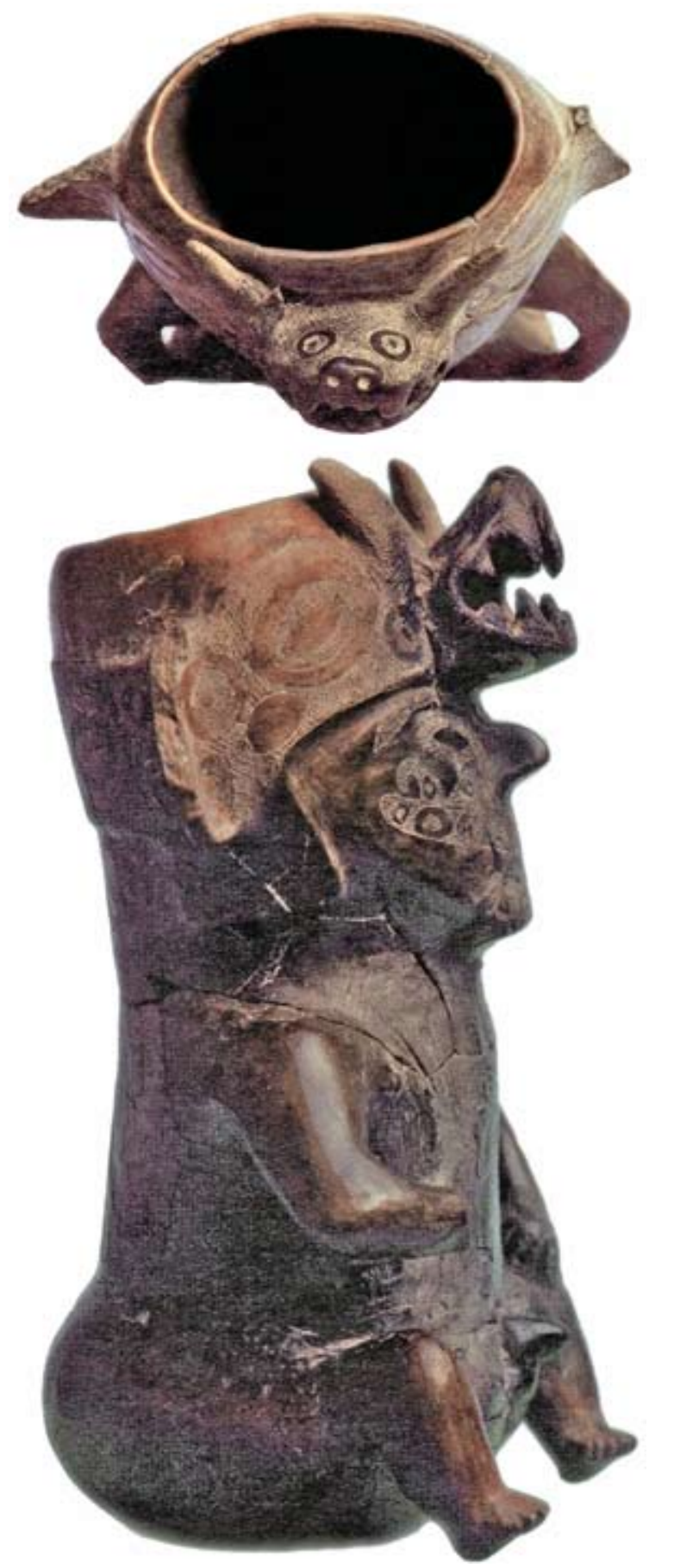

Figura 16. Vasija Aguada modelada con representación de personaje con atuendo cefálico de murciélago, atributo chamánico (tomado de González, A. R. 1998: 204-205).

Figure 16. Aguada modeled vessel with the representation of an individual wearing a bat headdress, a shamanic attribute (after González, A. R. 1998: 204-205).

El caso ilustrado por la figura 13 es particularmente interesante porque representa a una figura antropomorfa con una cabeza trofeo negra sobre cada uno de sus hombros y sin cabeza propia. ${ }^{14}$ En el lugar de ésta se dispone un espacio negativo con idéntica forma al rostro en "Y" de la figura de las largas cejas, generada en su parte superior por un triángulo pleno curvado idéntico al que presentan los rostros de las vasijas. Así se presenta un juego de espejos cada vez que la figura de las largas cejas porta en sus hombros como trofeos a guerreros (como sinécdoque), que a su vez llevan cabezas trofeos sobre los suyos. Resulta significativo el hecho de que la cabeza del guerrero grabada en la porción inferior de la coraza de cuero del río Loa publicada por Rydén (1944) haya sido representada con una estilización similar: el penacho, que tiene la misma forma en "Y" que las cejas de la figura de las urnas santamarianas, prácticamente reemplaza el lugar de la cabeza (fig. 17). Y también es muy sugerente el caso presentado por Luis González sobre la reutilización de un fragmento de mejilla de urna santamariana con representación de la cabeza del guerrero, como colgante en el cual la cabeza queda invertida (González, L. R. 2007: 46).

Mientras que los guerreros que portan corazas tienen todos adornos cefálicos en forma de penachos (fig. 15), los antropomorfos vestidos con túnicas presentan distintas formas de arreglo ornamental en sus cabezas. Si bien los penachos constituyen la forma más frecuente (casi el 50\% del total), también se registraron casos (dos) sin atuendo cefálico, con gorros (otros dos casos) y con gorro en una mejilla y penacho en la otra (cuatro casos). Los gorros pueden ser rectos o con dos puntas (fig. 14); los penachos en forma de tridigito, de plumas hacia arriba, o en forma de medialuna (fig. 15). Corazas y túnicas difieren en las decoraciones que son más frecuentes en cada uno de ellos. Mientras que en los primeros predominan las bandas gruesas diagonales (simples o cruzadas), diseños en forma de $V$ y pares de

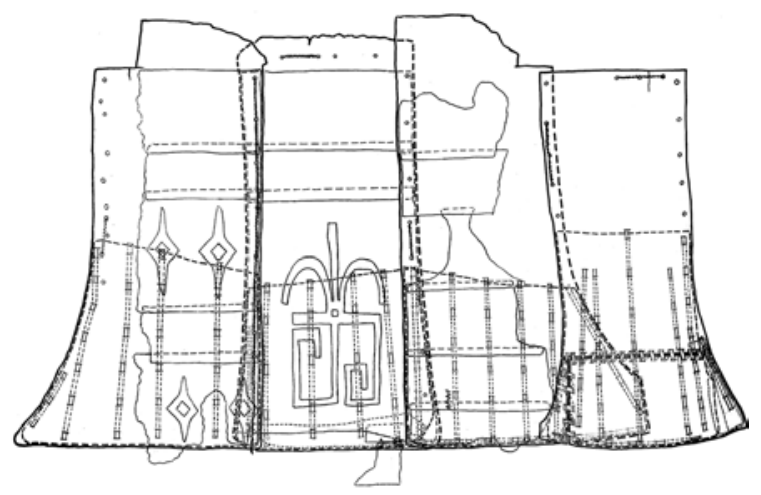

Figura 17. Coraza de cuero del río Loa con representación grabada de guerrero con penacho en su porción inferior (Rydén 1944). Figure 17. Leather cuirass from the Loa River. On its lower portion, the carved representation of a warrior with a crest (Rydén 1944). 
serpentiformes rectilineos en zigzag; en las túnicas el diseño predominante es una franja central vertical que la mayoría de las veces contiene guardas de escalonados espiralados rectos o bien serpentiformes o aviformes, pero siempre de modo individual (Nastri 1999: 394-396). Un único caso de escutiforme presenta una banda central vertical; en cambio ninguna de las túnicas que visten los antropomorfos tiene la decoración de bandas gruesas diagonales, ya sean simples o cruzadas, propias de las corazas. Veamos a continuación qué características presenta la decoración del sector de las vasijas en las cuales cabe esperar la representación de la vestimenta de la figura de las largas cejas.

\section{MOTIVOS Y ESTRUCTURAS DEL DISEÑO EN LOS CUERPOS DE LAS PIEZAS}

\section{La banda central vertical documentada en varias túnicas} de los guerreros de las mejillas de las urnas organiza la decoración tripartita del cuerpo de la figura de las largas cejas en más de la mitad de los ejemplares que componen la muestra considerada. Pudo representar la faja propiamente masculina, pero en ese caso habría sido como emblema antes que como exhibición de su función de uso (la faja se usa horizontalmente). ${ }^{15}$ Más significativo resulta el hecho de que se presente con la misma disposición vertical que en las corazas de los guerreros, lo cual sugiere un referente "real". Y también reforzaría su carácter masculino el considerar al motivo asociado de cordón quebrado como una forma estilizada de falo. En una urna Estilo Ambato tricolor (fig. 18) -correspondiente al Período Medio y publicada por Rex González (1998: 211)-, un personaje con largas cejas y decoración facial simétrica de cabezas de felino presenta un cuerpo pintado completo, incluyendo sus miembros inferiores. La sección basal del cuerpo se reservó para estos últimos y para el pene, que presenta una forma similar a la de la unión de los dos cordones quebrados de la cerámica santamariana. No obstante existe otro elemento que presenta una forma similar a la altura del pecho del personaje. Pareciera tratarse de un doble del pene (con los colores invertidos, pues el pene es gris y tiene un reticulado blanco pintado en el glande, mientras que la figura del pecho del personaje está pintada de blanco a excepción de la punta inferior, que mantiene el color gris), sobreimpuesto a lo que parece ser una banda central, similar a la de las urnas santamarianas. Entre una y otra figura se encuentra una especie de cinturón, oficiando de límite entre la sección basal y media del cuerpo, también de forma análoga a la división que a veces existe en las urnas santamarianas. De

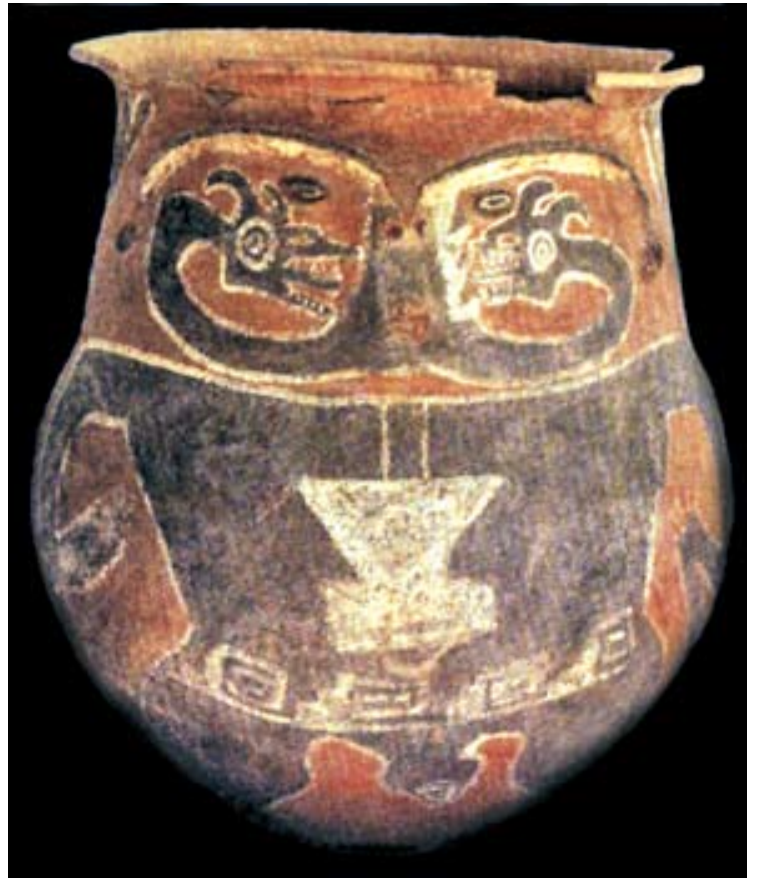

Figura 18. Urna Ambato tricolor con decoración antropomorfa, procedente de Ambato (tomado de González, A. R. 1998: 261). Figure 18. Ambato tricolor urn with antbropomorphic decoration, from Ambato (after González, A. R. 1998: 261)

modo que el cordón quebrado propio de la decoración de éstas (figs. $6,7,8,9,10,12$ ) tiene en común con la figura del pecho del personaje de la urna de Ambato su forma general y su disposición a ambos lados de la banda central, mientras que comparte con el motivo del pene el hecho de tener su culminación puntiforme en la sección basal de la pieza, por debajo de la línea divisoria horizontal.

Cabe señalar, finalmente, una última similitud del motivo del pecho de la urna de Ambato y del par de cordones quebrados de las urnas santamarianas con las figuras escutiformes. Los numerosos casos registrados en el arte rupestre surandino (Berenguer 1994; Tarragó et al. 1997: 232) también presentan una forma con la cual puede vincularse el motivo del par de cordones quebrados de las urnas santamarianas. En este sentido, el estrechamiento de los mismos correspondería al escotamiento de la cintura de las corazas (cf. Berenguer et al. 1985). Ambas interpretaciones no son totalmente excluyentes, en la medida en que la porción inferior de las corazas cubre la porción púbica de los combatientes.

Ambrosetti y Quiroga destacaron el aspecto fálico de representaciones de serpiente (Ambrosetti 1899: 162; Quiroga 1899: 336), colocando el segundo el énfasis principalmente en la vinculación de estos motivos con fenómenos atmosféricos. De esta manera, Quiroga identifica al relámpago-rayo en los zigzag descritos por el 


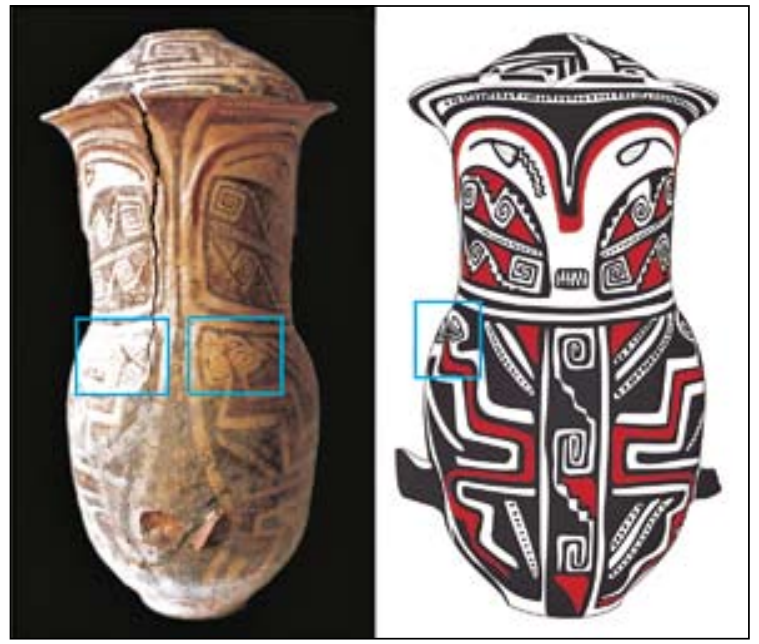

Figura 19. Motivo del cordón quebrado con terminación en forma de cabeza de serpiente (indicado por recuadro azul). Pieza del Museo Arqueológico Juan Bautista Ambrosetti (MAJBA), de Quilmes, Provincia de Tucumán.

Figure 19. Broken cord motif with termination in the form of a serpent head (indicated by a light blue box). Piece from Museo Arqueológico Juan Bautista Ambrosetti (MAJBA), Quilmes, Province of Tucumán. cuerpo de las serpientes, que se disponen muy frecuentemente tanto en los cuellos como en los cuerpos de las urnas (Quiroga 1992: 425). ${ }^{16}$ Principalmente, identificó al ser zoomorfo-celeste con las serpientes rectilíneas de cordón punteado que suelen ocupar dos de los cuatro campos de los cuellos de las urnas y de las cuales se desprenden peinetas (figs. $4 \mathrm{~d}$ y fig. 5 , Fase III). ${ }^{17} \mathrm{Mi}$ atención, en cambio, se dirige hacia casos tales como el de las figuras 19 y 20, los cuales constituyen buenos ejemplos de cómo el popular motivo "geométrico" de cordón quebrado, tan importante en la estructuración del diseño de las piezas con franja central en el cuerpo (en 202 casos), se manifiesta también como serpiente, al igual que en otros siete casos más. Su carácter quebrado y el hecho de que invariablemente aparezca representado en rojo, constituyen apoyos para la interpretación que asimila ambos elementos en la mitología calchaquí.

Respecto de la importancia del rayo en la vida de los antiguos aborígenes, resulta elocuente el siguiente relato de los jesuitas:

Cayó veloz un rayo no muy lejos de una india casada con un principal cacique [...] De aquí formaron agüero los hechiceros

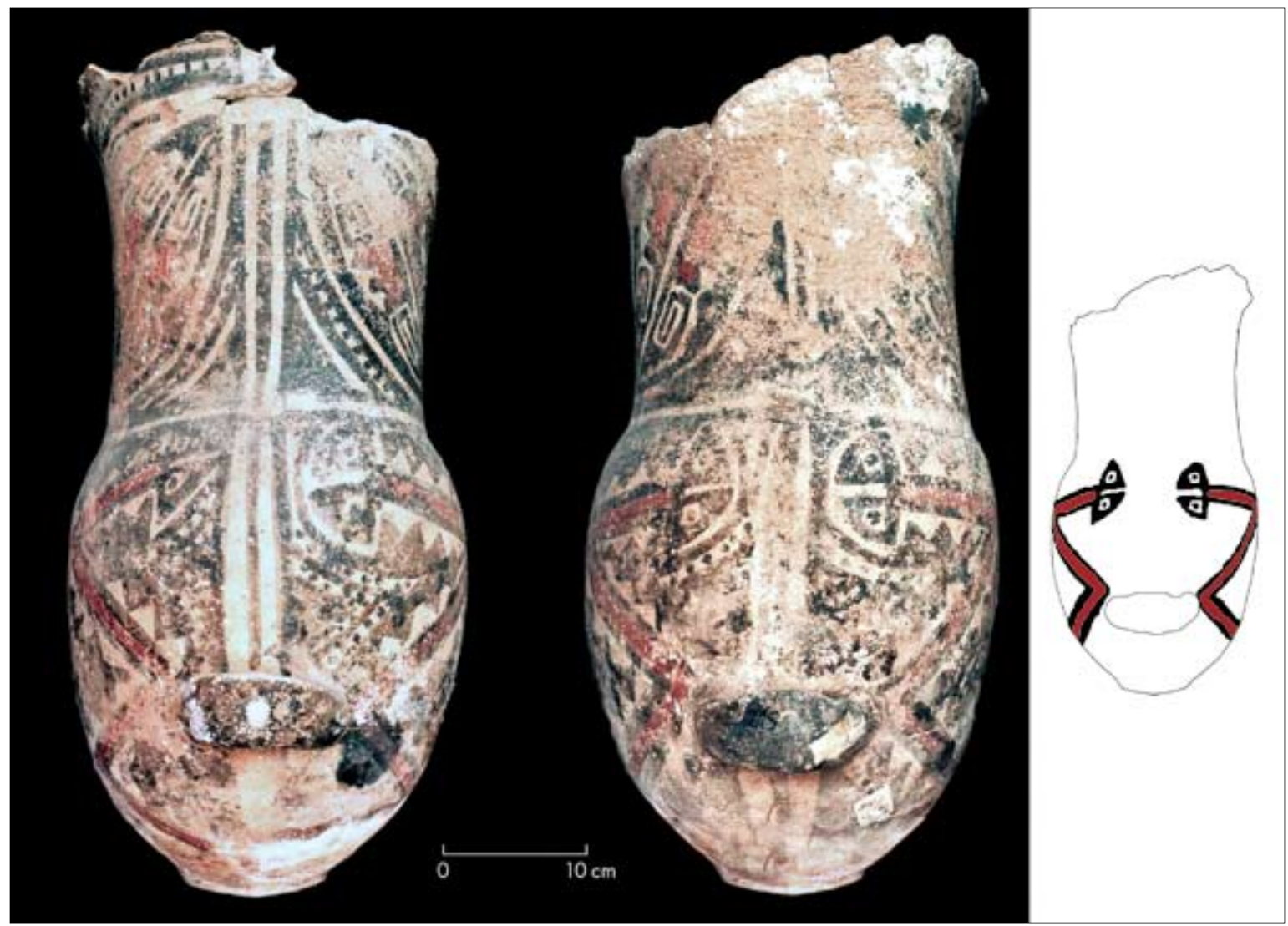

Figura 20. Motivo del cordón quebrado con terminación en forma de cabeza de serpiente. Pieza № 215 o $310 / 80$ (MAPEB). Figure 20. Broken cord motif with termination in the form of a serpent head. Piece $N^{\circ} 215$, or 310/80 (MAPEB). 
diciendo que era aquel presagio del cielo en que sus dioses mostraban querer a la venturosa india para sacerdotisa (Cartas Anuas de la Provincia del Paraguay, años 1653-1654, folios 47, 62-64; citado en Amigó 2000).

\section{También Lozano señalaba que:}

Adoraban al trueno, y al rayo, á quien tenían dedicadas unas casas pequeñas, en cuya circunferencia interior clavaban varas rociadas con sangre de carnero de la tierra, y vestidas de plumage de varios colores, á los cuales por persuación del padre de la mentira atribuían virtud de darles cuanto poseían (Lozano 1754 en González, A. R. 1983: 237).

Los significados que aparecen entonces como vinculables al tipo de decoración del cuerpo de las urnas con banda central, que se centran en torno al motivo del cordón quebrado, serían los siguientes: 1) el de lo masculino, por medio de la apariencia fálica del cordón quebrado; 2) el de la serpiente posible rayo, a partir de la transformación del mismo motivo en algunas piezas; 3) el del guerrero, a partir de la similitud de los cordones quebrados con las corazas militares y la frecuente decoración de éstas con serpientes rectilíneas. Por último, cabe agregar la asociación con el sacrificio en la pieza de la figura 21, la cual exhibe varias cabezas trofeo a lo largo del cordón quebrado. Entre los macha de Bolivia, Platt (1978) documentó que, existiendo en la cosmovisión andina una dimensión divina superior (el lugar de los astros) y otra inferior (en el interior de la tierra), y viviendo los hombres en una dimensión intermedia, el rayo puede provenir tanto de lo alto como de lo bajo, dejando sin vida aquello que toca y también resucitándolo. Esta noción habría resultado perfectamente coherente con una función de las urnas como repositorios de un cuerpo cuya energía vital se habría buscado que volviera a la tierra para reencarnarse en el futuro en una nueva persona, dejando así de perturbar a los vivos (Platt
2001). El hecho de que el cordón quebrado, ya sea en su forma vertical (a ambos lados de la franja central del cuerpo con división tripartita) u horizontal (en las piezas con división de brazos: por encima de éstos o bien en la sección basal [fig. 5, Fase II]), sea, luego del rostro, el motivo con presencia más constante a lo largo de la muestra, señala que su significación pudo haber tenido un carácter central en el contexto de la función de las urnas, como podría ser el caso de la noción del rayo vigente entre los macha. ${ }^{18}$

La otra gran forma de organizar las representaciones en el cuerpo de las piezas es la de los brazos de la figura de las largas cejas que se juntan hacia el centro del cuerpo de la vasija, ya sea sosteniendo o no un puco, en aparente actitud de ofrenda (figs. 11, 13, 14, 22). Los casos pintados (propios de las fases III a V) casi duplican a los modelados (135 contra 71). El lugar privilegiado de la decoración es la porción media del cuerpo, por encima de la curva que describen los brazos, pues por debajo de éstos usualmente se repiten motivos paralelos (por ejemplo, cordones punteados) a modo de "relleno", hasta el lugar en que se dispone el motivo de triángulo curvado hacia arriba, que marca el límite con la sección basal de la pieza.

Atendiendo a los tipos de decoración por encima de los brazos, cabe distinguir tres grandes grupos: los que presentan pares de motivos figurativos, los que contienen motivos de cordones quebrados e indiformes y los que consisten en dameros o reticulados. En los últimos dos tipos se mantiene el predominio numérico de los casos pintados observado en el conjunto total (65 contra 28 y 37 contra 14, respectivamente), pero en el primero existe un equilibrio: 32 casos de brazos pintados contra 28 modelados. Este hecho refleja en buena medida la gran popularidad del motivo del ñandú a lo largo de toda la secuencia. En el conjunto de piezas con división

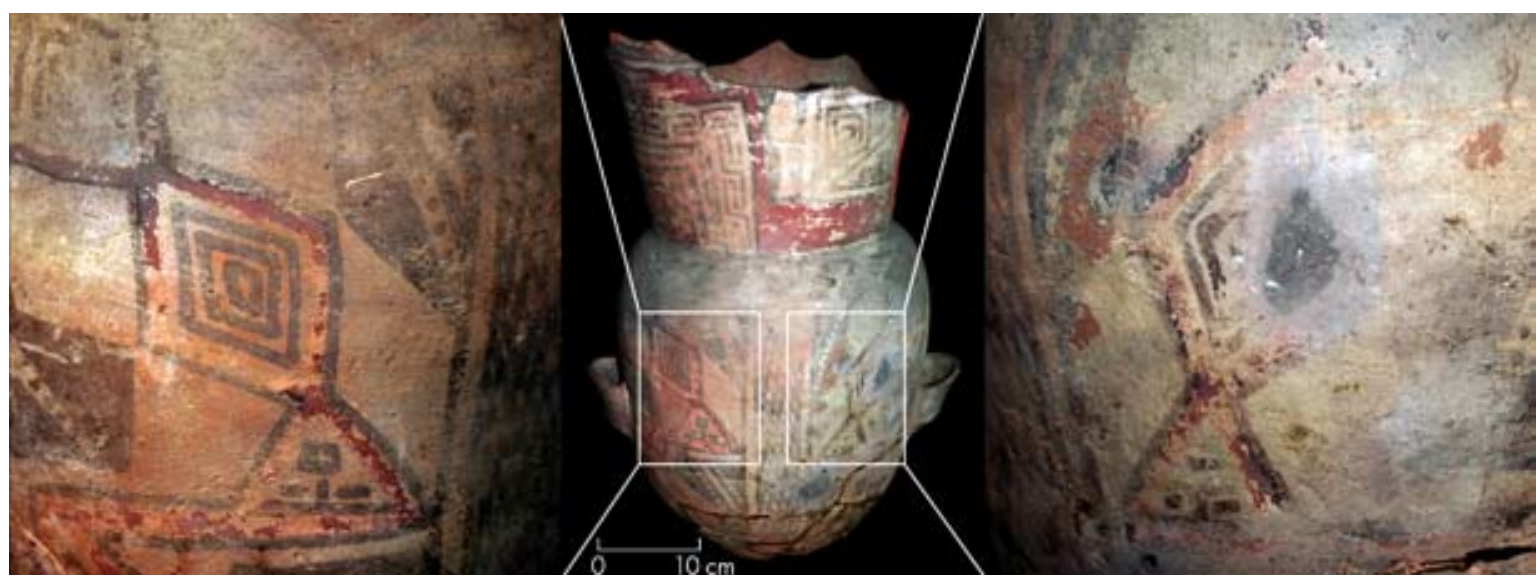

Figura 21. Motivo del cordón quebrado incluyendo representaciones de cabezas cercenadas. Pieza No 73-116 (MEJBA). Figure 21. Broken cord motif, with severed head representations. Piece $N^{\circ}$ 73-116 (MEJBA). 
de brazos en el cuerpo, 39 presentan ñandúes, 13 serpientes y sólo siete batracios. La importancia del ñandú fue destacada por Quiroga, quien, como se dijo, apeló a observaciones acerca del comportamiento del mismo en vísperas de tormenta. ${ }^{19}$ No dejó de advertir tampoco la importancia de las varillas "emplumadas" como protección de las sementeras, tal como cuenta Lozano (González, A. R. 1983); en los "templos del Trueno y del Rayo", de los cuales habla el Padre Guevara, y en el adorno de los árboles a los que adoraban, según afirma el Padre Techo (Quiroga 1901: 156).

Los ñandúes efectivamente suelen tener sus cabezas orientadas hacia las manos o puco de la figura de las largas cejas (sólo en un 15\% de los casos "miran" hacia los laterales de la vasija), y en la mayoría de los casos (18 contra 10, más seis indeterminados) portan una cruz en el lomo, ya sea del tipo andino o consistente en dos líneas cruzadas de igual longitud. Cuando no llevan cruz, su lomo presenta espirales, triángulos espiralados, círculos, reticulados, dameros o triángulos. Sólo tres piezas con cuerpo con división de brazos presentan ñandúes felinizados, en contraste con el mayor número de casos que se documentaron en las piezas con división tripartita en el cuerpo. Otras tres piezas, de fases IV y V, presentan ñandúes que portan una serpiente en su boca.

Del conjunto de piezas que tienen pares de serpientes, cabe destacar que sólo en tres casos se trata de serpientes bicéfalas. Su ubicación en el contexto de la pieza muy probablemente implique un significado diferente al de otras serpientes del arte santamariano. En este sentido es llamativo otro tipo de representación exclusivo de esta ubicación: cuerpo rojo lleno de puntos (véase fig. 11). A diferencia de las serpientes más comunes de las mejillas (rectilíneas, de fondo blanco y con sólo una hilera de puntos o motas) y del cordón quebrado-serpiente, del cuerpo (también rectilíneo y rojo, sin puntos), éstas son curvas, gruesas y tienen puntos más pequeños dispuestos en forma desordenada.

Existe otro modo de organización de la estructura de diseño en el cuerpo de las urnas que, de la misma manera que los brazos de la figura de las largas cejas, genera dos campos curvos a la altura de lo que sería el pecho de ésta: se trata de lo que denominamos serpientebrazos: dos líneas gruesas que en lugar de terminar en manos confluyen en la cabeza de una serpiente (fig. 4c). Cabe distinguir entre aquellas piezas (tardías, así también como otras procedentes de la zona nororiental) en las cuales la transformación es mayor (las líneas son más gruesas), de aquellas en que la diferencia con los habituales brazos sólo reside en el reemplazo de las manos por la cabeza de serpiente.
Finalmente, cabe destacar que en las urnas de la parte final de la seriación hay piezas que tienen en la porción superior de la sección media del cuerpo apéndices modelados de cabezas humanas, los cuales pueden ser interpretados como cabezas trofeo (Nastri 2007; figs. 22 y 23). En el caso de la urna de la figura 24, las manos de la figura de las largas cejas sostienen una cabeza cortada. Otras dos urnas Fase IV, ilustradas en las figuras 15 y 25 , presentan el dibujo de cabezas cercenadas en las bandas laterales de las vasijas. La ubicación de estas cabezas (al derecho y al revés) se da en este caso por debajo de los hombros, aproximadamente en la cintura de la figura de las largas cejas. Si bien en las crónicas se menciona la práctica del seccionamiento de la cabeza del enemigo vencido (Nastri 1999: 373), hasta el momento sólo se tiene registro de una cabeza cercenada en contexto arqueológico tardío en Tinogasta (Cigliano 1965), al suroeste de la región calchaquí. A propósito de la urna para adulto Estilo Hualfín que contenía dicho resto, Rex González advirtió la dualidad presente en la decoración de esa pieza entre ambas caras de la misma (González, A. R. 1974: 48), quedando de manifiesto una gran similitud con los modos de generación de la diferencia sutil en el arte santamariano.

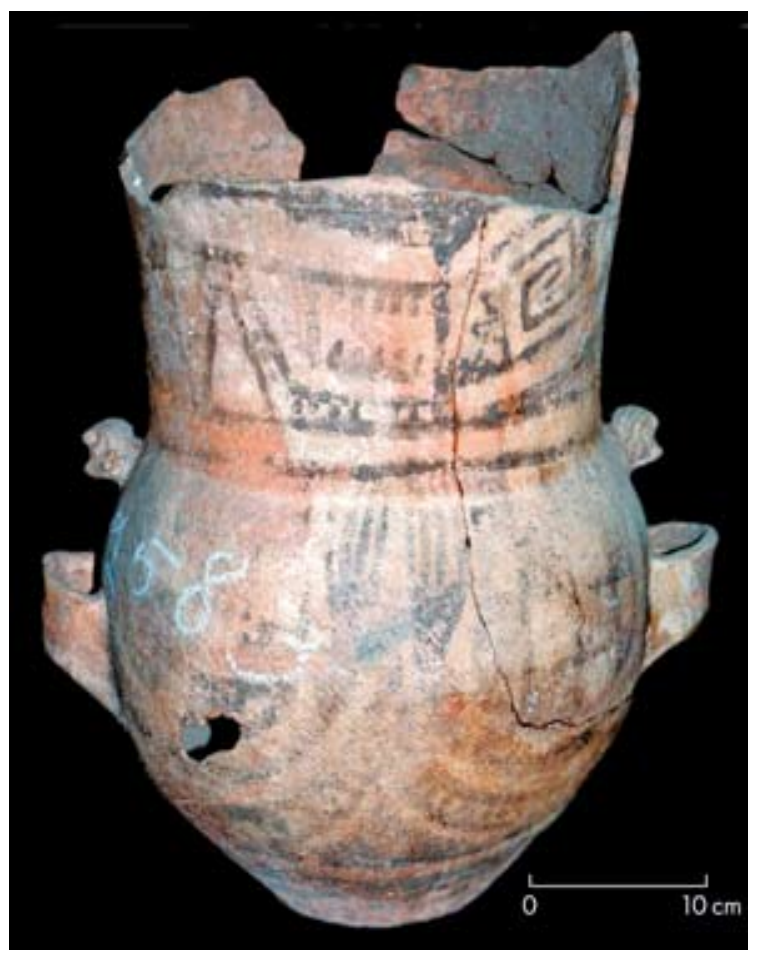

Figura 22. Apéndices de cabezas humanas modeladas en los laterales de la pieza $\mathrm{N}^{\circ} 2583$ (MLP).

Figure 22. Modeled human head appendages on the sides of piece $N^{\circ} 2583$ (MLP). 


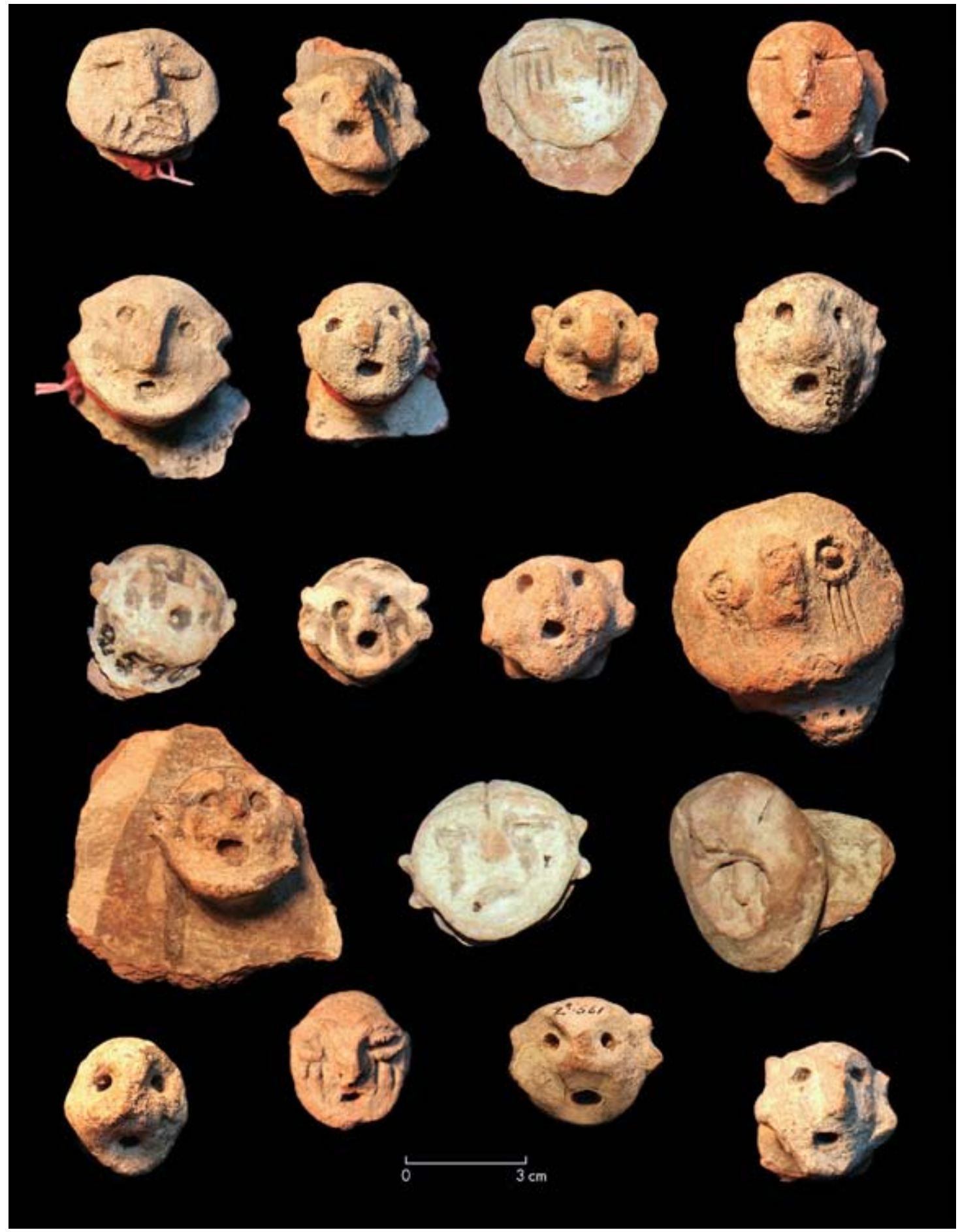

Figura 23. Apéndices de cabezas humanas modeladas de urnas santamarianas de las colecciones Zavaleta. De izquierda a derecha y de arriba abajo, fragmentos $N^{\circ}: 29262$ y 29275 (MEJBA); VC4463 (EM), procedente de Fuerte Quemado; Z-7723, Z-7693, Z775, 25967, Z7758 (MEJBA); VC 6046 (EM) procedente de Fuerte Quemado; Z-7717, Z7720, 29266, 29255 (MEJBA); VC6033 (EM) procedente de Fuerte Quemado y VC5218 (EM) procedente de "Pallogasta-Cachi"; 25992, 29262, 25957, y Z7729 (MEJBA).

Figure 23. Santamariana urn modeled head appendages, Zavaleta collections. From left to right, and top to bottom: fragments $N^{\circ}$ : 29262 and 29275 (MEJBA); VC4463 (EM), from Fuerte Quemado; Z-7723, Z-7693, Z775, 25967, Z7758 (MEJBA); VC 6046 (EM), from Fuerte Quemado; Z-7717, Z7720, 29266, 29255 (MEJBA); VC6033 (EM), from Fuerte Quemado, and VC5218 (EM) from "Pallogasta-Cachi"; 25992, 29262, 25957, and Z7729 (MEJBA). 


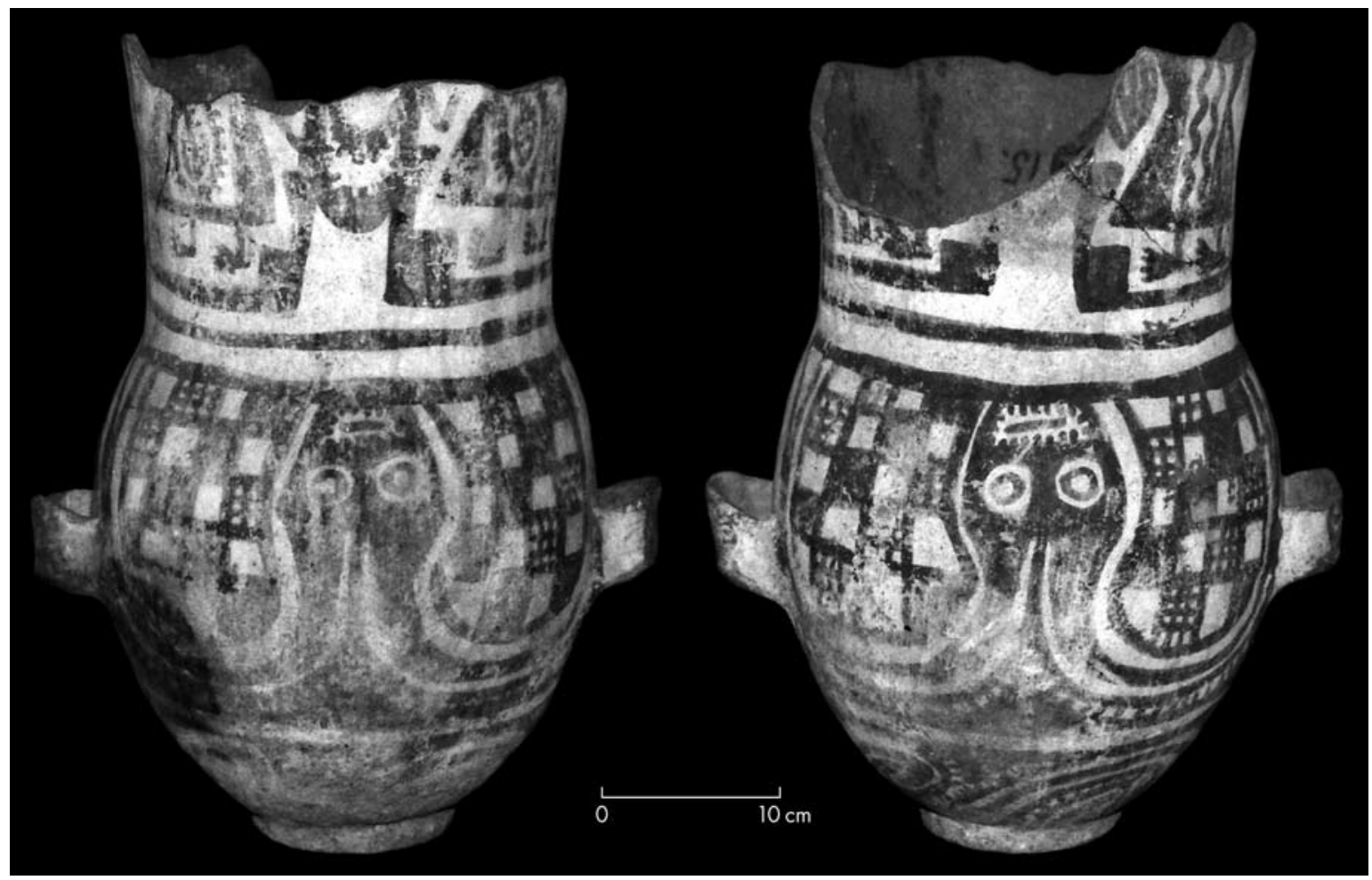

Figura 24. Representación de la figura de las largas cejas portando una cabeza cercenada en el lugar que habitualmente ocupa la representación de un puco. Pieza No VC5954 (EM, colección Zavaleta).

Figure 24. Representation of the long-eyebrowed figure holding a severed head in an area normally occupied by a puco (shallow dish or plate) drawing. Piece $N^{o}$ VC5954 (EM, Zavaleta collection).

\section{DISCUSIÓN}

El rico corpus de imágenes que contienen las urnas santamarianas y el conocimiento arqueológico existente tras más de un siglo de investigaciones, proporciona elementos de juicio para discutir la cuestión de la cosmovisión calchaquí, lo cual, a su vez, constituye una vía de gran relevancia para la mejor comprensión de la forma de vida y organización social de esta sociedad. Si por cosmologías entendemos a las ontologías de la praxis generales, compartidas por un sinnúmero de sociedades y en buena medida inconscientes, con el término cosmovisión se hace referencia a la "aproximación existencial que el indígena tiene acerca de la totalidad que lo rodea -incluyendo al universo-, así como las formas que adoptan el hombre y la comunidad para relacionarse con él" (Martínez Sarasola 2004: 24). Este último carácter más específico constituye el objeto de la interpretación iconográfica de este trabajo, mientras que la inclusión de la cosmovisión calchaquí en alguna de las cosmologías definidas por Descola (2006) se relaciona, en lo que respecta al dato de las imágenes, con la interpretación iconológica.
La evidencia iconográfica analizada en este trabajo sugiere la presencia de representaciones con atributos chamánicos como los atavíos cefálicos de cabezas de animales; un probable énfasis en indicaciones fálicas en las fases tempranas y medias de la seriación; claras referencias a prácticas sacrificiales en el marco de expresiones agresivas; selección de un repertorio de animales (ñandú, serpiente, sapo) que se adosa a la figura de las largas cejas como si ésta tuviera poder sobre aquéllas. Respecto de la representación de los atributos especiales del chamán, Llamazares (2004: 105) destaca

[...] el sobredimensionamiento de la cabeza y/o de las manos con relación al resto del tamaño del cuerpo. La cabeza, particularmente, parece ser el símbolo por excelencia del lugar dentro del cuerpo humano donde reside el poder chamánico. Las imágenes de cabezas destacadas por sus formas y dimensiones se relacionan seguramente con la importancia de la mente y la visión -ambas alojadas en la cabeza- en la práctica chamánica. ${ }^{20}$

Si nuestra interpretación de la representación del rayo en el cuerpo de las vasijas es correcta, se trataría entonces, además, de la simbolización "del poder sobrenatural o divino del chamán” que, junto con los ornamentos cefálicos (cabezas de animales, mascarillas 


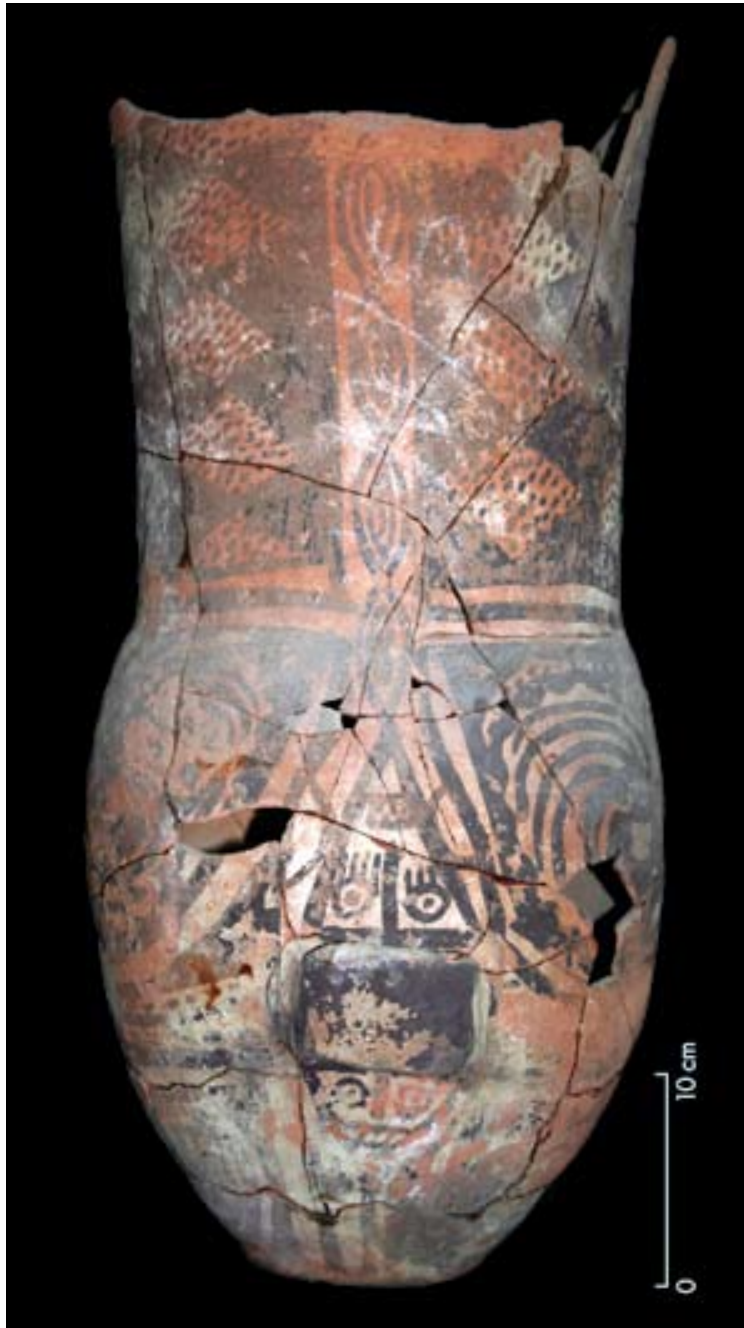

Figura 25. Representación pintada de cabeza trofeo sobre la banda lateral de la pieza $N^{\circ} 4528$ (MLP). Procedencia: El Bañado (colección Muñiz Barreto).

Figure 25. Trophy head representation painted on the lateral band of piece $N^{\circ} 4528$ (MLP). Source: El Bañado (Muñiz Barreto collection).

metálicas, etc.) como "representación del prestigio y poder terrenal", constituyen los dos tipos de atributos especiales del mismo (Llamazares 2004: 105).

A su vez, en el mencionado caso del probable rayo "alterado" en serpiente, así como también en las serpientes bicorpóreas que se disponen como los brazos de la figura central; en el rostro de la vasija que se conforma de ñandúes; los ojos brillantes de los sobrerostros y los de la decoración arquitectónica, etc., todos estos casos apuntan a destacar procedimientos retóricos (metáfora, metonimia) que expresan una multiplicación de vinculaciones entre diferentes términos, sugiriendo la presencia de una cosmología analogista; la misma que se corresponde, según Descola (2006), con las socie- dades andinas. El que las campanas metálicas también representaran a las cabezas trofeo (Pérez de Arce 2001 en González, L. R. 2007: 46), refuerza la idea de una generalización del modo de identificación analogista. Ahora, dado que los contextos chamánicos más conocidos etnográficamente corresponden a sociedades animistas, es necesario determinar mejor la función chamánica en el recientemente definido marco analogista, así como también la posible articulación de elementos de ambas ontologías en contextos socioculturales específicos como el calchaquí.

Swenson (2003: 284) señala que en los Andes la violencia ritual fue "[...] un importante mecanismo que permitió a los grupos explotar efectivamente las asimetrías existentes y tomar ventaja de las cambiantes condiciones ecológicas y económicas". La transformación de la función chamánica en sacerdotal y viceversa (o entre chamanismo vertical y horizontal) constituye un cambio histórico de primer orden que requiere de una profunda investigación. La larga duración de las tradiciones estilísticas del Noroeste Argentino y el conocimiento de sus cambios progresivos otorgan la posibilidad de estudiar la mencionada transformación a lo largo del tiempo, una vez que los argumentos originalmente orgánicos de las seriaciones estilísticas son reemplazados por contenido simbólico o narrativo (Nastri 2005-2006). Por ejemplo, el hecho de que la noción de "sacrificadorsacrificado" se introdujera hacia el final de la secuencia santamariana sugiere que podría ser el caso de que la sociedad calchaquí pasara de un estado más jerárquico a uno más igualitario a lo largo de los siglos de su desarrollo. Pues dicha noción, como señalara Viveiros de Castro (2005: 344-345), es propia de las sociedades caracterizadas por el chamanismo horizontal. Y si bien por cuestiones de espacio no podemos desarrollar en esta ocasión el tema de la decoración geométrica de los cuellos de las urnas sin rostros de la Fase 0 (véase fig. 5), en el caso de que las mismas refirieran a momias envueltas en textiles (Velandia Jagua 2005: 115-116) y, por ende, a ancestralidad (Isbell 1997), abonaría la interpretación de un tránsito desde una religión más institucionalizada (sacerdocio o chamanismo vertical) a otra menos compleja (chamanismo horizontal). Lejos de sostener una dirección irreversible del cambio en la adopción de alguno de los mencionados tipos de chamanismo o sacerdocio, considero que una interpretación detallada de las imágenes proporciona un camino útil para la reconstrucción de la contingencia histórica. Esta última incluye también a las interacciones e influencias de zonas vecinas, como las tierras bajas orientales, tal como han explorado algunos autores (González, A. R. 1979; Weber 1981). Este factor puede 
haber sido responsable de algunos giros "inesperados" en las secuencias supuestamente progresivas hacia la complejización.

Finalmente, cabe señalar que en este trabajo se ha puesto el énfasis en la identificación de significaciones hasta el momento no advertidas (sobre-rostros, cabezas trofeo, diferencia sutil, etc.), que tienen relevancia respecto de la cosmovisión y organización política calchaquí. No se ha considerado la cuestión de la relación entre los casos que cuentan con los motivos analizados y aquellos que, siendo comparables, presentan motivos diferentes. Se trata de un tema que requiere de un desarrollo analítico específico (Nastri 2008), en relación con el cual cabe adelantar dos posibilidades interpretativas. En primer lugar puede tomarse al conjunto de representaciones de la figura de las largas cejas de cada fase como manifestaciones de un mismo significado. Las variaciones entre los casos se interpretan en términos de opciones tomadas por el artista particular a los fines de expresar ciertos atributos o características en lugar de otros. En este sentido, se trataría de permutaciones de elementos equivalentes, algunos de los cuales presentan en ciertos ejemplares una manifestación preiconográfica más explícita a los fines de nuestra comprensión, constituyendo de este modo indicios (Guinzburg 1989) para la interpretación del sentido del resto de los casos de la serie. ${ }^{21}$ La segunda alternativa consiste en considerar que en torno a la figura de las largas cejas se desplegó una variación de significados en sincronía. Por ejemplo, que las piezas con sobre-rostros representaban chamanes, pero no así los que no tienen sobre-rostros. Que las que tienen cabezas trofeo representaron sacrificadores, mas no así las figuras de las largas cejas que portan pucos en sus manos.

La disyuntiva interpretativa planteada puede ser superada mediante la apelación a nuevas categorías que permitan organizar la masa de datos empíricos a los fines de la comparación y la cuantificación de los mismos. Los conceptos de alteración, como modificación de una cualidad (Gadamer 1977: 155) del motivo; permutación, como sinónimo expresivo entre distintas piezas, de una misma unidad constitutiva o mitema (Lévi-Strauss 1958: 204), y transformación, como cambio completo (Gadamer 1977: 155) en el significado de dicha unidad, se revelan como instrumentos potencialmente útiles para el análisis. Su empleo permitiría exponer más claramente la carga interpretativa de cada escenario planteado. De esta manera, una cabeza cercenada en manos de la figura de las largas cejas puede entenderse en términos de una permutación del puco, que tomamos como indicio de una identidad de significado entre ofrenda y sacrificio. Los sobre-rostros pueden tomarse también como un indicio del referente chamán, en la permutación de formas de representación de la cabeza de la figura de las largas cejas, o bien como una alteración de esta última que otorgaría a algunas de las urnas una jerarquía por sobre las otras, o bien funciones especiales. Por último, las referidas piezas sin rostro de la Fase 0 (fig. 5), o con rostros en posición más marginal en urnas de cuello "estirado" (fig. 5, Fase V) representarían una efectiva transformación del significado de la figura de las largas cejas desde una concepción previa como momia y hacia una nueva concepción en términos de serpiente, respectivamente.

De la misma manera, cabe señalar que una afinación de las herramientas descriptivas requiere también la diferenciación entre distintas significaciones para las diferentes formas de representación de la serpiente, del cordón quebrado, etc. Así como los esquimales cuentan con una infinidad de términos para aludir a los distintos tonos de blanco, puede pensarse que en relación con los motivos principales del arte santamariano, la gama de variación tuviera una importancia más significativa de lo que en principio podemos reconocer. En definitiva, se trata de embarcarse en el juego propuesto por los productores del estilo, entre la identidad y la diferencia.

\section{CONCLUSIONES}

A lo largo de este trabajo he buscado exponer el gran potencial informativo que reside en el corpus de imágenes del estilo santamariano para avanzar en el conocimiento de aspectos relevantes en torno a la organización social y política calchaquí. El análisis en detalle de los motivos y temas representados y de sus variaciones en una amplia muestra permite desarrollar hipótesis, con distintos grados de probabilidad, acerca de los significados iconográficos e iconológicos plasmados en las vasijas. Representaciones de la autoridad y de prácticas vinculadas a la misma, en un marco cosmológico hipotético para la sociedad en cuestión y dispuestas en un marco de variación cronológico y geográfico controlado (tarea en buena medida pendiente aún), posibilitarán el planteo de una trayectoria propiamente histórica, por ejemplo en relación al tipo de institucionalidad religiosa de la sociedad calchaquí.

Tratándose de un sistema de carácter sacrificial, la escasez de registros escritos acerca de la mitología calchaquí no constituye un obstáculo tan grande para la interpretación de las imágenes, como podría suponerse en un principio. Pues en el marco de los modos de identificación animista y analogista, puede suponerse 
que la significación secundaria de temas y motivos responde más a vínculos retóricos (metáfora, metonimia, sinécdoque) antes que alegóricos y narrativos. La cantidad de imágenes y su enorme variación dentro de convenciones representativas relativamente constantes hace de la iconografía calchaquí un ámbito altamente relevante para la ampliación del conocimiento sobre las ontologías de la praxis referidas y el sentido de las nociones y prácticas del sacrificio y el chamanismo dentro de las mismas.

La sociedad calchaquí participó activamente de esa gran esfera de intercambio económico y cultural que llamamos mundo andino. Esta esfera, como cualquier otra comparable, varió en sus dimensiones a lo largo del tiempo, además de incluir una gran variedad y una dinámica interna. El análisis de los significados de las imágenes asociadas a prácticas rituales se revela como una promisoria vía para alcanzar una comprensión de la organización social calchaquí y sus cambios asociados al devenir: una particular forma de arte constituye la materialización de un modo de experiencia (Geertz 1994: 123). Comprender el arte santamariano implica pues involucrarse en una vivencia de las formas y los colores, en un marco simbólico original y en un conjunto de prácticas del pasado. El presente trabajo pretende contribuir con el avance sobre una de las distintas líneas de evidencia (iconografía) que, articuladas, permitirán una mejor comprensión de los originales universos sociales desarrollados por las sociedades precolombinas que habitaron la región en estudio.

RECONOCIMIENTOS A Gisela Spengler, por la confección de las figuras. A Gerónimo Pratolongo, por acompañarnos en el inicio de nuestros relevamientos en museos y por la lectura crítica y corrección de textos preparatorios de este trabajo. A Myriam Tarragó, por su apoyo durante la redacción de la tesis doctoral. A Manuela Fischer; José Pérez Gollán, Adriana Callegari, Gabriela Amirati; Rodolfo Raffino; Rubén Quiroga; Mirta Santoni, Christian Vitry; María Antonella Fugazzola del Pino, Carlo Nobili, por haber hecho posible y facilitado nuestra labor respectivamente en los museos de Berlín; Etnográfico de la Universidad de Buenos Aires; de La Plata; de Santa María; de Salta; y Pigorini de Roma. A Victoria Coll, Ana Vargas, Milena Acha, Gabriel Caruso, Romina Spano, Carlos Belotti de Medina, Jennifer Baigorria y Emily Wiggens, por su ayuda en distintas etapas del desarrollo de la investigación. A Guillermo Wilde, por el enriquecedor intercambio sobre aspectos teóricos de las cosmovisiones amerindias. A Ana Fernández, por acercarnos datos empíricos de interés. De nuevo a Gitty, por todo.

\section{NOTAS}

${ }^{1}$ Se ha constituido una muestra compuesta por 832 piezas de estilos tardíos correspondientes a las colecciones Muñiz Barreto, Moreno, Lafone Quevedo, Methfessel, Ten Kate y Bruch del Museo de La Plata; Zavaleta, Quiroga, Ambrosetti y Breyer, del Museo Etnográfico de la Facultad de Filosofía y Letras de la Universidad de Buenos Aires; Zavaleta, Schmidt y Uhle, del Museo Etnológico de Berlín; Schreiter, del Museo Etnográfico de Viena; Ambrosetti, del Museo Pigorini de Roma; Salvatierra y otros, del Museo Eric Boman de Santa María. 756 de los ejemplares que componen el corpus compilado corresponden a urnas santamarianas, fundamentalmente de la variedad Yocavil. Dicha cifra constituye el total de referencia de aquí en más.

${ }^{2}$ Si bien el Período Tardío en la Subárea Valliserrana del Noroeste Argentino comprende el lapso entre el 900 y 1480 DC (Tarragó 1999), estudios estadísticos y de calibración radiocarbónica realizados sobre el conjunto de fechados disponibles para la localidad de Rincón Chico conducen a ubicar el comienzo de la ocupación tardía para el siglo xi de la Era (Greco 2005), considerando el "pico" en la distribución de probabilidades de las fechas comprendidas en el rango de edades radiocarbónicas (Holdaway 2006: 140). Esto es coincidente con lo planteado respecto del cercano asentamiento de Pichao (Cornell \& Johansson 1993; Greco 2005), para el cual también existe un conjunto amplio de fechados radiométricos. Durante los siguientes períodos, Imperial (1480-1536) e Hispano-Indígena (1536-1650), la población autóctona continuó siendo la misma -los calchaquíes, productores de vasijas estilo santamariano- a la cual se sumaron primero los invasores inkaicos y luego los hispanos. Por esta razón cuando nos referimos a tiempos o poblaciones tardías estamos aludiendo al conjunto de los tres períodos.

${ }^{3}$ De acuerdo con informes de los jesuitas, los aborígenes calchaquíes efectivamente se pintaban el rostro (Compañía de Jesús 1990: 52-53)

${ }^{4}$ Quiroga denominó al personaje central de las vasijas ídolo de las largas cejas (Quiroga 1896: 187).

${ }^{5}$ Son 34 los casos que se apartan del canon habitual de representación del rostro de la figura de las largas cejas en el cuello de las vasijas. Motivos no figurativos tales como dameros, reticulados y cordones quebrados horizontales adquieren así protagonismo en este sector de las piezas.

${ }^{6}$ Como ejemplo bien vale la propuesta de Bovisio (1993) de considerar la situación de distancia existente entre los asistentes al ritual y las placas metálicas en poder de los oficiantes del culto, durante el Período de Integración Regional, en el contexto de centros ceremoniales como La Rinconada de Ambato, en la provincia de Catamarca.

${ }^{7}$ En cuanto a la situación comunicacional en la que participaron las urnas santamarianas en la vida cotidiana en los poblados, poco sabemos aún (Piñeiro 1996: 168).

${ }^{8}$ Quiroga ve en la postura del ñandú una disposición a la carrera que interpreta motivada por la cercanía de la lluvia (Quiroga 1992: 432), pues dicho animal anuncia la inminente tormenta con un comportamiento nervioso y movedizo. Se ha planteado que tal comportamiento responde a que en dicha circunstancia su plumaje se carga de electricidad estática (Tarragó, comunicación personal).

${ }^{9}$ Ambrosetti realizó sus recopilaciones en el extremo norte del valle de Santa María y en la porción sur del valle Calchaquí, de Tolombón a Cachi, en la provincia de Salta (fig. 2).

${ }^{10}$ En la arquitectura calchaquí se ha documentado en varios sitios un rasgo que resulta muy sugerente en relación al papel que la idea de "ojos brillantes" pudo tener en los antiguos sistemas de representaciones. El mismo estuvo dado por la inserción de bloques de cuarzo blanco en el lado externo de los muros, lo cual, sobre todo bajo el reflejo del sol, causa en el observador la impresión de unos ojos relucientes (Reynoso 2003: 137; Tarragó \& González 2004; Nastri \& Vietri 2004: 395).

${ }^{11} \mathrm{El}$ hecho de que se trate de una oposición binaria referida al cuerpo de un personaje antropomorfo condujo a Weber (1981: 19) a plantear que dicha distinción correspondería a la indicación de género, en base a una asociación de lo masculino con verticalidad y lo femenino con horizontalidad en la vestimenta de tribus amazónicas.

${ }^{12}$ De ser acertada esta interpretación, estaríamos ante un caso de figura bipartida (González, L. R. 2007: 82), en la cual dos figuras de perfil (cabezas de ñandú) conforman una figura diferente (ojos antropomorfos), de frente. 
13 En el corpus completo hay 17 piezas con antropomorfos con túnica, otras 17 con antropomorfos con corazas; tres que tienen de ambos tipos; uno que no corresponde a ninguno de los dos, y finalmente dos que tienen antropomorfos-serpentiformes atomizados.

${ }^{14}$ Raúl Mandrini publicó recientemente una carta del Padre Alonso de Bárzana de fines del siglo xvi, en la cual hace referencia a la religión calchaquí: "Acerca de la religión o culto de todas las naciones que pertenecen a la provincia de Tucumán no he hallado que tengan ídolos ningunos a quienes hayan adorado; hechiceros sí tienen y han tenido muchos, de los cuales algunos les hacían adorar al mismo Demonio, que siempre les aparecía negro y que les ponía temor" (Bárzana en Mandrini 2004: 122). Véase más adelante que la indudable cabeza trofeo de la pieza de la figura 24 también es negra.

15 Entre los habitantes rurales de los valles, Ambrosetti (1953: 135) documentó la creencia en la existencia del alma o espíritu que podía desprenderse del cuerpo en ciertas ocasiones, por ejemplo cuando una persona enfermaba. Entonces se buscaba a una médica, quien averiguaba los lugares por donde había andado el enfermo antes, y a la noche se dirigía a los mismos en compañía de dos gritadores, arrastrando una prenda del enfermo: si éste era varón, su faja; si era mujer, su rebozo. Quiroga relata una situación de "fuga del espíritu" ocurrida en Tolombón, en donde las pertenencias que representan al enfermo son un ceñidor, su sombrero y su pañuelo blanco "que no sepa pecar" (Quiroga 1926: 222).

${ }^{16}$ En su análisis del mito de Huayrapuca o "Madre del viento", un ser mitológico de gran difusión en la América precolombina (bajo distintos nombres), Quiroga apeló a testimonios de los pobladores rurales, destacando que en "Los Cardones y Amaicha se tienen a la Centella y al Rayo por parientes suyos muy próximos. La centella es hembra y varón el rayo" (Quiroga 1992: 344).

${ }^{17}$ Quiroga registró una estrecha vinculación entre la divinidad de la Madre del viento y la serpiente: "Interrogando a las gentes de los valles qué clase de auxilio presta al mito la serpiente para volar, se me contestó: ¿no ve que la serpiente no tiene alas, y salta largo y vuela también? Y, efectivamente, lo de las serpientes voladoras, es la cosa más corriente en Calchaquí. Cuando Huayrapuca tiene, entonces, larga cola de serpiente, es claro que vuela" (Quiroga 1992: 344). Resulta entonces sugerente el hecho de que las peinetas adosadas a las serpientes rectilíneas de cordón punteado hayan sido representadas igual que manos (de humanos y batracios) y que alas de aves.

${ }^{18}$ A partir de la Fase IV, la preferencia por motivos figurativos también en el cuerpo pudo haber sido causa de la restricción del motivo de cordón quebrado a la sección basal, tal como ocurría en el cuello con los motivos de guerreros, que "tapaban" las mejillas y su decoración geométrica, al disponerse como cráneos trofeo sobre los hombros de la figura de las largas cejas. El abandono del color rojo también contribuyó a restarle impacto visual al motivo.

19 Otro hecho determinante para Quiroga, aparte del hecho que el ñandú "anuncie" con su comportamiento nervioso la proximidad de la tormenta, reside en que muy frecuentemente el ave es representada con una serpiente saliendo de su boca, como si se tratase de una nube de la cual se despiden descargas eléctricas. Y en los casos en que las urnas cuentan con representación de brazos que sostienen un puco, los ñandúes tienen por lo general sus cabezas contiguas a éste, como si estuvieran por verter agua en él (Quiroga 1901: 152).

${ }^{20}$ Teniendo en cuenta esta relación, el "achicamiento" del rostro en las urnas Fase V (Nastri 2005-2006: 254-255; fig. 5) representaría un corte en la secuencia de mayor importancia que lo advertido en los aspectos técnicos y morfológicos.

${ }^{21}$ En su estudio inaugural de los mitos, Lévi-Strauss (1958: 204) usa el término permutación para aludir a los cambios que existen en un mismo elemento de una historia mítica (mitema o unidad constitutiva), entre una versión y otra.

\section{REFERENCIAS}

Agüero Vera, J. Z., 1972. Divinidades diaguitas. Cuadernos de Humanitas 41. San Miguel de Tucumán: Universidad Nacional de Tucumán.

Ambrosetti, J. B., 1899. Notas de arqueología calchaquí. Buenos Aires: Imprenta y Litografía La Buenos Aires.

---- 1953. Supersticiones y leyendas. Santa Fe: Librería y Editorial Castellví.

Amigó, M. F., 2000. El desafío de Calchaquí. Un puñado de jesuitas "entre un mar de indios". La intervención de la Compañía de Jesús en el valle Calchaquí (siglos xvi y xviI). Tesis de Licenciatura en Ciencias Antropológicas, Facultad de Filosofía y Letras, Universidad de Buenos Aires.

Berenguer, J., 1994. Asentamientos, caravaneros y tráfico de larga distancia en el norte de Chile: el caso de Santa Bárbara. En De costa a selva. Producción e intercambio entre los pueblos agroalfareros de los Andes Centro Sur, M. E. Albeck, Ed., pp. 17-50. San Salvador de Jujuy: Instituto Interdisciplinario de Tilcara, Facultad de Filosofía y Letras, Universidad de Buenos Aires.

Berenguer, J.; V. Castro; C. Aldunate; L. Cornejo \& C. Sinclaire, 1985. Secuencia de arte rupestre en el Alto Loa: una hipótesis de trabajo. En Estudios de arte rupestre, C. Aldunate, J. Berenguer, \& V. Castro, Eds., pp. 87-108. Santiago: Museo Chileno de Arte Precolombino.

Bovisio, M. A., 1993. La imagen del poder, el poder de las imágenes en la plástica precolombina del NO argentino. En Arte y poder. vJornadas de Teoría e Historia de las Artes, pp. 326-337. Buenos Aires: Centro Argentino de Investigadores de Artes.

Bregante, O., 1926. Ensayo de clasificación de la cerámica del Noroeste Argentino. Buenos Aires: Editorial Ángel Estrada y Cía.

Callens, S., 2006. "Philippe Descola, Par-delà nature et culture, Paris, Gallimard, 2006, 618 p.", Développement durable et territoire, Publications de 2006, mis en ligne le 17 septembre 2006. <http:// developpementdurable.revues.org/document2954.html>

Caviglia, S., 1985 Ms. Las urnas para niños de los valles Yocavil y Calchaquí. Su interpretación sobre la base de un enfoque gestáltico. Seminario de Arqueologia I, Buenos Aires.

Cigliano, E. M., 1965. Un hallazgo en "Baranca Larga". El yacimiento arqueológico del Mojón 747 de la ruta Tinogasta-Belén (provincia de Catamarca). Anales de Arqueología y Etnología 20: 37-48, Mendoza.

Compañía De Jesús, 1990. Cartas Anuas de la Provincia del Paraguay 1632-1634. Con introducción y notas de J. A. Maeder. Buenos Aires: Academia Nacional de la Historia.

Cornell, P. \& N. Johansson, 1993. Desarrollo del asentamiento del sitio STucTav 5 (El Pichao), Provincia de Tucumán. Comentarios sobre dataciones de $14 \mathrm{C}$ y luminiscencia. Publicaciones del Instituto de Arqueología 2 (1 Investigaciones): 31-43, Tucumán.

Descola, P., 1992. Societies of nature and the nature of society. En Conceptualizing society, A. Kuper, Ed., pp. 107-126. London: Routledge.

2006. Beyond nature and culture. Proceedings of the British Academy 139: 137-155. Oxford: University Press.

Gadamer, H. G., 1977. Verdad y método. Barcelona: Ediciones Sígueme.

Geertz, C., 1994. Conocimiento local. Barcelona: Paidós.

González, A. R., 1974. Arte, estructura y arqueología. Buenos Aires: Nueva visión.

— 1977. Arte precolombino de la Argentina. Introducción a su bistoria cultural. Buenos Aires: Filmediciones Valero.

— 1979. Dinámica cultural del NO argentino. Evolución e historia en las culturas del NO argentino. Antiquitas 28-29: 1-15, Buenos Aires.

- 1983. Nota sobre religión y culto en el Noroeste Argentino prehispánico. Baessler-Archiv, Neue Folge Band XXXI: 219279, Berlin.

— 1998. Cultura La Aguada. Arqueología y diseños. Buenos Aires: Filmediciones Valero. 
González, A. R. \& J. A. Pérez., 1972. Argentina indígena. Vísperas de la conquista. Historia argentina 1. Buenos Aires: Ediciones Paidós.

GonZÁLEZ, L. R., 2007. Tradición tecnológica y tradición expresiva en la metalurgia prehispánica del Noroeste Argentino. Boletín del Museo Chileno de Arte Precolombino 12 (2): 33-48, Santiago.

Gordillo, I., 1990. Entre pirámides y jaguares. Ciencia Hoy 2 (8):18-25, Buenos Aires.

Greco, C., 2005. Dataciones y eventos arqueológicos en la localidad de Rincón Chico, Valle de Yocavil, Catamarca. En Primer Congreso Argentino de Arqueometría, A. Pifferetti \& R. Vommaro, Eds., pp. 312-323, Rosario.

Guinzburg, C., 1989. Mitos, emblemas, indicios. Morfología e bistoria Barcelona: Gedisa Editorial.

Hodder, I., 1990. Style as historical quality. En The uses of style in archaeology, M. Conkey \& C. Hastorf, Eds., pp. 44-51. Cambridge: Cambridge University Press.

- 1993. The narrative and rhetoric of material culture sequences. World Archaeology 25 (2): 268-282. London: Routledge.

Hugh-Jones, S., 1996. Shamans, prophets, priests and pastors. En Shamanism, history, and the state, N. Thomas \& C. Humphrey, Eds., pp.32-75. Ann Arbor: University of Michigan Press.

Holdaway, S., 2006. Absolute dating. Archaeology in practice. A student guide to archaeological analyses, J. Balme. \& A Paterson, Eds., pp. 117-158. Blackwell: Oxford.

IsBeLL, W., 1997. Mummies and mortuary monuments: A postprocessual prehistory of Central Andean social organisation. Austin: University of Texas Press.

Johansson, N., 1996. Burials and society. A study of social differentiation at the site of El Pichao, NW Argentina, and in cemeteries dated to the Spanish Native Period, GOTARC, Series B, Gothenburg Archaeological Theses 5. Göteborg: Department of Archaeology, Göteborg University.

Lafone Quevedo, S., 1892. Catálogo descriptivo e ilustrado de las Huacas de Chañar Yaco (Provincia de Catamarca). Revista del Museo de La Plata 3: 35-63, Buenos Aires.

LÉvi-STrauss, C., 1958. Antropología estructural. Buenos Aires: Editorial Eudeba.

— 1964. El pensamiento salvaje. México D. F.: Fondo de Cultura Económica.

— 1992. Historia de lince. Barcelona: Editorial Anagrama.

LlamaZARES, A. M., 2004. Arte chamánico: visiones del universo. En $E l$ lenguaje de los dioses, A. M. Llamazares \& C. Martínez Sarasola, Eds., pp. 67-126. Buenos Aires: Editorial Biblos.

MANDRINI, R., 2004. Los pueblos originarios de la Argentina. La visión del otro. Buenos Aires: Editorial Eudeba.

Marchegiani, M., 2008. Estilo y cronología. Los cambios en la cerámica funeraria de Rincón Chico entre los siglos x y xvII DC. En Estudios Arqueológicos en Yocavil, M. Tarragó \& L. González, Eds., pp. 128-175. Buenos Aires: Asociación de Amigos del Museo Etnográfico.

Marchegiani, M.; V. Palamarczuk \& A. Reynoso, 2007. El estilo como frontera. Sobre las urnas negro sobre rojo de momentos tardíos de Yocavil (Noroeste Argentino). Actas del XVI Congreso Nacional de Arqueología Argentina, Vol. II, pp. 451-456. San Salvador de Jujuy: Universidad Nacional de Jujuy.

Martínez Sarasola, C., 2004. El círculo de la conciencia. Una introducción a la cosmovisión indígena americana. En El lenguaje de los dioses. Arte, chamanismo y cosmovisión indígena en Sudamérica, A. M. Llamazares \& C. Martínez Sarasola, Eds., pp. 21-66. Buenos Aires: Editorial Biblos.

Mendes Do Santos, G., 2002 Ms. Naturaleza e culturas. I Seminário Matogrossense de Etnobiologia e Etnoecologia e II Seminário Centro-Oeste de Plantas Medicinais. <http://www.ufmt.br/ etnoplan/artigos/Naturezas\%20e\%20Culturas.PDF>

NASTRI, J., 1999. El estilo cerámico santamariano de los Andes del Sur (siglos XI a xvI). Baessler-Archiv, Neue Folge Band 47: 361-396, Berlin

— 2003. Aproximaciones al espacio calchaquí. Anales 6: 99125, Göteborg.
- 2005-2006. El simbolismo en la cerámica de las sociedades tardías de los valles calchaquíes (siglos XI a XVI). Arqueología 13: 253-261, Buenos Aires.

— 2007. La lógica del sacrificio en la iconografía calchaquí. En Actas del XVI Congreso Nacional de Arqueología Argentina, Vol. II, pp. 457-462. Universidad Nacional de Jujuy: San Salvador de Jujuy.

— 2008. La noción de transformación en arqueología antropológica. En Perspectivas actuales en arqueología argentina, R. Barberena, K. Borrazo \& L. Borrero, Eds. Buenos Aires: Iмнісінu (en prensa).

NAStri, J. \& L. Vietri, 2004. I Calchaqui, cento anni dopo. Note sulla collezione Ambrosetti. Bullettino di Paletnologia Italiana 95: 355-377. Roma: Ministero per i Beni e le Attività Culturali, Soprintendenza Speciale al Museo Nazionale Preistorico Etnografico "L. Pigorini", Istituto Poligrafico e Zecca dello Statu.

Palamarczuk, V., 2008. Un análisis de la cerámica arqueológica de cuatro sitios en el bajo de Rincón Chico. En Estudios Arqueológicos en Yocavil, M. Tarragó \& L. González, Eds., pp. 20-80. Buenos Aires: Asociación de Amigos del Museo Etnográfico.

PANOFSKY, E., 1979. Estudios sobre iconología. Madrid: Alianza Editorial.

_ 1983. El significado en las artes visuales. Madrid: Alianza Editorial.

Pazos, A., 2006. Recensión crítica "Philippe Descola, Par-delà nature et culture, Paris: Éditions Gallimard, 2005, 623 páginas". AIBR. Revista de Antropología Iberoamericana 1 (1): 186-194. Madrid: Antropólogos Iberomericanos en Red. ISSN: 1578-9705 [online]. <http://www.aibr.org/antropologia/01v01/ libros/010101.pdf>

PiñeIRO, M., 1996. Manejo de recursos y organización de la producción cerámica en Rincón Chico. Catamarca. Relaciones de la Sociedad Argentina de Antropología 21: 161-185, Buenos Aires.

PlatT, T., 1978. Symétries en miroir. Le concept de Yanantin chez les Macha de Bolivie. Annales ESC 33: 1081-1107, Paris.

— 2001. El feto agresivo. Parto, formación de la persona y mito-historia en los Andes. Anuario de Estudios Americanos 57: 633-678, Sevilla

Perrota, E. \& C. Podestá, 1974. Seriación con valor cronológico de una colección de urnas y pucos santamarianos del valle de Yocavil. Ponencia al III Congreso Nacional de Arqueología Argentina, Salta.

Podestá, C. \& E. Perrota, 1973. Relaciones entre culturas del Noroeste argentino. San José y Santa María. Antiquitas 17: 6-15, Buenos Aires.

Price, N. (ED.), 2001. The Archaeology of Shamanism. New York: Routledge.

Quiroga, A., 1896. Antigüedades calchaquíes. La colección Zavaleta. Boletín del Instituto Geográfico Argentino 17: 177-210, Buenos Aires.

_ 1899. El simbolismo de la cruz y el falo en Calchaquí. Boletín del Instituto Geográfico Argentino 19: 305-343, Buenos Aires.

— 1901. La cruz en América. Buenos Aires. Imprenta y Litografía La Buenos Aires.

— 1926. La fuga del espíritu. Biblos 11: 221-225, Buenos Aires. 1992. Calchaquí. Reedición conjunta de: "Calchaquí" (1897); Petroglifos y pictografías calchaquíes" (1931); y "Folklore calchaquí" (1929). Buenos Aires: TEA Ediciones.

Reichel-Dolmatoff, G., 1988. Orfebreria y chamanismo. Un estudio iconográfico del Museo del Oro. Medellín: Editorial Colina.

Reynoso, A., 2003. Arqueoastronomía en Rincón Chico (Catamarca, Argentina). Monumentos del tiempo, monumentos del encuentro en el valle de Yocavil. Anales 6: 127-161, Göteborg.

Rice, P., 1987. Pottery analysis: A sourcebook. Chicago: The University of Chicago Press.

RYDÉn, S., 1944. Contributions to the archaeology of the Rio Loa Region. Göteborg: Elanders Boktryckeri Aktiebolag. 
Segre, C., 1985. Principios de análisis del texto literario. Barcelona: Editorial Crítica.

Steimberg, O., 1993. Semiótica de los medios masivos. Buenos Aires: Editorial Atuel.

Swenson, E., 2003. Cities of violence. Journal of Social Archaeology 3 (2): 256-296, Oxford.

TARragó, M., 1999. Las sociedades del Sureste Andino. En Historia General de América Latina, Vol. 1, Las sociedades originarias, unesCo, Ed., pp. 465-480. México: Trotta Editorial.

2000. Chacras y pukara. Desarrollos sociales tardíos. En Nueva bistoria argentina, Vol. 1, M. Tarragó, Ed., pp. 257-300. Buenos Aires: Editorial Sudamericana.

TARragó, M. \& L. GonzÁlez, 2004. Arquitectura social y ceremonial en Yocavil, Catamarca. Relaciones de la Sociedad Argentina de Antropología 29: 297-316, Buenos Aires.

TARragó, M.; L. GonzÁlez \& J. NASTRI, 1997. Las interacciones prehispánicas a través del estilo: el caso de la iconografía santamariana. Estudios Atacameños 14: 223-242, San Pedro de Atacama.

Velandia Jagua, C., 2005. Iconografia funeraria en la cultura Santa Maria, Argentina. Ibagué: Universidad de Tolima.

Viveiros De Castro, E., 2005. Chamanismo y sacrificio: un comentario amazónico. En Chamanismo y sacrificio. Perspectivas arqueológicas y etnológicas en sociedades indígenas de América del Sur, J. P. Chaumeil, R. Pineda Camacho \& J. F. Bouchard, Eds., pp. 335-347. Bogotá: Banco de la República - Instituto Francés de Estudios Andinos.

Weber, R., 1978. A seriation of the late prehistoric Santa Maria culture of Northwestern Argentina. Fieldiana Anthropology 68: 49-98, Chicago.

1981. An analysis of Santa Maria urn painting and its cultural implications. Fieldiana Anthropology 2: 1-32, Chicago. 